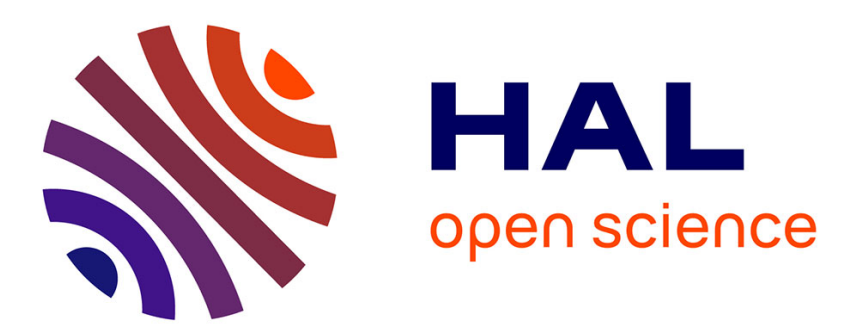

\title{
Mechanosynthesis of carbonate and lithium co-substituted hydroxyfluorapatite
}

Hanen Hajji, Sophie Le Gallet, Lucien Saviot, Ezzedine Ben Salem, Nadine Millot

\section{- To cite this version:}

Hanen Hajji, Sophie Le Gallet, Lucien Saviot, Ezzedine Ben Salem, Nadine Millot. Mechanosynthesis of carbonate and lithium co-substituted hydroxyfluorapatite. Materials Research Bulletin, 2022, 150, pp.111750. 10.1016/j.materresbull.2022.111750 . hal-03548824

\section{HAL Id: hal-03548824 https://u-bourgogne.hal.science/hal-03548824}

Submitted on 31 Jan 2022

HAL is a multi-disciplinary open access archive for the deposit and dissemination of scientific research documents, whether they are published or not. The documents may come from teaching and research institutions in France or abroad, or from public or private research centers.
L'archive ouverte pluridisciplinaire HAL, est destinée au dépôt et à la diffusion de documents scientifiques de niveau recherche, publiés ou non, émanant des établissements d'enseignement et de recherche français ou étrangers, des laboratoires publics ou privés. 


\title{
Mechanosynthesis of carbonate and lithium co-substituted hydroxyfluorapatite
}

\author{
Hanen Hajji ${ }^{1,2 *}$, Sophie Le Gallet ${ }^{2}$, Lucien Saviot $^{2}$, Ezzedine Ben Salem ${ }^{1}$ and Nadine Millot ${ }^{2 *}$ \\ ${ }^{1}$ I.P.E.I. of Monastir, University of Monastir, Unit of materials and organic synthesis UR17ES31
} Monastir 5019, Tunisia

${ }^{2}$ Laboratoire ICB UMR 6303 CNRS/Université Bourgogne Franche-Comté, Dijon, France

* corresponding authors: nmillot@u-bourgogne.fr, hananhaiji02@gmail.com

\begin{abstract}
The presence of fluoride, lithium and carbonate group within hydroxyapatite occurring naturally within the body provides the basis for investigating the sintering ability of co-substituted hydroxyfluorapatites nanopowders for use as biomaterials. $\mathrm{Ca}_{10-\mathrm{x}} \mathrm{Li}_{\mathrm{x}}\left(\mathrm{PO}_{4}\right)_{6-\mathrm{x}}\left(\mathrm{CO}_{3}\right)_{\mathrm{x}}(\mathrm{OH}) \mathrm{F}$ nanopowders, with $\mathrm{x}$ equal to 0 , $0.5,1,1.5,2$ and 2.5 were prepared using mechanosynthesis and their extensive characterization was realized. Substitution causes contraction of the unit hexagonal cell along the $a$-axis and elongation along the $c$-axis, as well as a decrease in the degree of crystallinity of the powders, and an increase of the amounts of unreacted calcium and lithium carbonates. Crystallite sizes and strains, determined by the Halder \& Wagner method, remain the same whatever x. Spectroscopic analyses show that B-type carbonated apatite is formed. Annealing at $500^{\circ} \mathrm{C}$ improves the crystallinity of the apatite phase with low percentages of calcite and lithium phosphate as secondary phases $(\mathrm{x} \leq 2)$. Transmission electron microscopy observations show that untreated and calcined powders consist mainly of spherical nanoparticles. As-mechanosynthesized $\mathrm{Ca} 9 \mathrm{Li}\left(\mathrm{PO}_{4}\right)_{5}\left(\mathrm{CO}_{3}\right)(\mathrm{OH}) \mathrm{F}$ powder, sintered by Spark Plasma
\end{abstract}


Sintering, densifies in the temperature range of 580 to $650{ }^{\circ} \mathrm{C}$. The crystallite size remains the same than that of the untreated-powder (about $15 \mathrm{~nm}$ ).

Key words: Mechanosynthesis, Nanoparticles, Hydroxyfluorapatite, $\mathrm{Li}^{+}$and $\mathrm{CO}_{3}{ }^{2-}$ substitution, Sintering

\section{Introduction}

Biomaterials are widely used in the medical field, for example to replace or repair defective hard tissues in the human body. These biomaterials can be divided into four categories: calcium phosphatebased bioceramics, metals and alloys, polymers and materials of natural origin. Bioceramics contain various species commonly found in bones such as $\mathrm{Ca}^{2+}, \mathrm{PO}_{4}^{3-}, \mathrm{Mg}^{2+}, \mathrm{Na}^{+}, \mathrm{Sr}^{2+}, \mathrm{F}^{-}$and $\mathrm{OH}^{-} \ldots[1]$. Apatite is a large privileged family of calcium phosphates, which has been extensively studied during the last few decades. Their general formula is $\mathrm{M}_{10}\left(\mathrm{XO}_{4}\right)_{6} \mathrm{Y}_{2}$ where $\mathrm{M}$ is a divalent cation, $\mathrm{Y}$ a monovalent anion and $\mathrm{XO}_{4}$ a trivalent anion. Apatite generally crystallizes in the $\mathrm{P}_{3} / \mathrm{m}$ space group (hexagonal lattice) [2].

Apatite are used in various applications particularly in the chemical fertilizer industry [3], in surgery as bone substitutes [4], for fluoride phosphor lamps [5], in pharmacy and in chromatography as a catalyst, for luminescence [6], laser materials, fuel cells [7] and conditioning matrices for nuclear materials [8]. Hydroxyapatite and fluorapatite are the best-known compounds of this family [9]. The flexibility of this structure opens the door to total or partial substitution in the cationic and anionic networks [10]. $\mathrm{Ca}_{10}\left(\mathrm{PO}_{4}\right)_{6} \mathrm{~F}(\mathrm{OH})(\mathrm{HFA})$ is a well-known biomaterial involved in dental and bone formation in the body [11]. When used as an implant, HFA does not cause an inflammatory cellular response. It is naturally present in tooth enamel with $\mathrm{F}^{-}$ions replacing $\mathrm{OH}^{-}$up to $50 \%$. $\mathrm{HFA}$ and fluorapatite are also less soluble and more stable than hydroxyapatite [12]. 
Different synthesis methods have been used to prepare apatite: solid-solid reaction at high temperature [12], precipitation in an aqueous medium [13], hydrolysis by hydrothermal process [14], sol-gel [15] and mechanosynthesis [16]. The powder obtained by each of these methods has different crystallo-chemical and morphological characteristics. Mechanosynthesis is a relatively new method for synthesizing calcium phosphate. It is suitable to prepare nanopowders [17]-[19]. High-energy ball milling presents many advantages for industrial applications where simplicity and high productivity are of paramount importance. The grains undergo successive fracture and welding processes due to repeated shocks during grinding. Planetary mills are powerful tools for synthesizing particles of different sizes and morphologies [20], [21]. Mechanosynthesis is a complex process requiring the optimization of a number of milling parameters to obtain the desired product phase. Coreño et al [22] suggested that the advantage of the mechano-synthesis method is that the surface-bound species are disrupted by pressure to improve the thermodynamic and kinetic reactions between the solids. The resulting nanocrystalline HFA are relevant for applications in the biomedical and clinical fields. Indeed, HFA nanostructures can have improved mechanical properties [23], [24]. Significant improvements in the resistance and tenacity of pure HFA have also been obtained through incorporation of different types of additives. However, studies of the properties of lithium-doped apatite are still limited. O. Kaygili et al [25] demonstrated that lithium reduces the solubility of HA. Li-substitution increases the thermal stability compared with other cations such as $\mathrm{Sr}, \mathrm{Mg}$, and $\mathrm{Si}$ [26][28]. The insertion of lithium into the hydroxyfluorapatite structure also enhances toughness, osteogenesis-bioactivity and strength. This increase of strength was assigned to the decrease of porosity which results in a more compact and harder structure. Moreover, Mayer et al [28] and Popescu et al [29] have demonstrated that the absorption of $\mathrm{Li}^{+}$by $\mathrm{HFA}$ does not change the lattice structure and that lithium causes a decrease in the solubility of carbonated hydroxyapatite which is directly related to biocompatibility. 
The incorporation of carbonate groups in the apatite structure is also of particular importance [30], [31]. Carbonate substitution in fluorapatite (FA) and hydroxyapatite (HA) has been studied in depth by radiography of monocrystals, Raman and Infrared (IR) spectroscopies as well as neutron powder diffraction [32]-[34]. Carbonates either are in the tetrahedral phosphate sites (B-type) or in the structural channels located on the hexagonal axis of symmetry (A-type). Each site leads to specific IR and nuclear magnetic resonance (NMR) spectroscopic signatures. Sometimes the carbonate groups are located in both sites (A-B type) [35]-[37]. Despite numerous studies, detailed atomic-scale models of apatite carbonate groups are still under discussion.

Classic high-temperature sintering processes often alter the physico-chemical characteristics, notably surface reactivity and therefore the biological properties of apatite. In addition, they are responsible for the decomposition of non-stoichiometric apatite. Spark plasma sintering (SPS) is a nonconventional sintering technique based on the use of pulsed current, allowing higher heating and cooling rates, lower sintering temperatures and preserving the grains and nanostructures [8]. The consolidation at very low temperature of nanocrystalline apatite thanks to SPS has already been reported and is very promising. Mechay et al. [9] and Drouet et al. [38] have indeed shown that SPS consolidation limits the physico-chemical modifications of the initial powder and preserves the size of the nanocrystals, leading to compacts with high mechanical strength. Drouet et al. [38] observed that with other uni-axial pressure assisted sintering methods, the physico-chemistry and secondary phases are more affected than with SPS.

In this paper, HFA co-substituted with carbonate and lithium ions have been prepared by mechanosynthesis followed by thermal annealing. The powders have been fully characterized by different structural, chemical and morphological techniques before and after annealing. The substituted HFA with $x=1$ (as-mechanosynthesized) was sintered using SPS at $800^{\circ} \mathrm{C}$. 


\section{Experimental procedure}

A planetary ball mill (Retsch PM200) was used for the mechanosynthesis of nanopowders of hydroxyfluorapatite. The powder of the starting reagents and $10 \mathrm{~mm}$ stainless steel balls were introduced in both $46 \mathrm{~mm}$ stainless steel jars. The jars were placed on a $248 \mathrm{~mm}$ diameter disc. The mass of the balls is approximately $4 \mathrm{~g}$. For a disc rotation speed of $450 \mathrm{rpm}$ and a jar rotation speed of $900 \mathrm{rpm}$ the injected shock power is about $29 \mathrm{~W} / \mathrm{g}$ and the cumulative shock energy is about $318 \mathrm{~J}$ [39]. The shocks between the wall of the jar, the balls and the powder increase the temperature resulting in the formation of aggregates. Therefore, after a milling time of $26 \mathrm{~min}$, a rest period of $4 \mathrm{~min}$ was necessary to limit the formation of these aggregates. The synthesis reaction is as follows:

$$
\begin{aligned}
(10-\mathrm{x}) \mathrm{CaCO}_{3}+(\mathrm{x} / 2) \mathrm{Li}_{2} \mathrm{CO}_{3}+\mathrm{NH}_{4} \mathrm{~F}+(6-\mathrm{x})\left(\mathrm{NH}_{4}\right)_{2} \mathrm{HPO}_{4}+(3 \mathrm{x} / 2)\left(\mathrm{NH}_{4}\right)_{2} \mathrm{CO}_{3} & \longrightarrow \\
\mathrm{Ca}_{10-\mathrm{x}} \mathrm{Li}_{\mathrm{x}}\left(\mathrm{PO}_{4}\right)_{6-\mathrm{x}}\left(\mathrm{CO}_{3}\right)_{\mathrm{x}}(\mathrm{OH}) \mathrm{F}+10 \mathrm{CO}_{2}+9 \mathrm{H}_{2} \mathrm{O}+(13+\mathrm{x}) \mathrm{NH}_{3}(\text { with } 0 \leq \mathrm{x} \leq 2.5) & \text { (Eq. 1) }
\end{aligned}
$$

The as-prepared powders were calcined for $1 \mathrm{~h}$ at $500^{\circ} \mathrm{C}$ under air to remove undesirable residual species.

$0.3 \mathrm{~g}$ of as-prepared powder was also sintered under vacuum by Spark Plasma Sintering (SPS) using a HPD-10 device (FCT System, Germany) with $10 \mathrm{~mm}$ diameter graphite molds. A heating ramp of $50^{\circ} \mathrm{C} / \mathrm{min}$ was applied up to $800^{\circ} \mathrm{C}$ while applying a pressure of $75 \mathrm{MPa}$ for the dilatometric test. Pressure was maintained during the natural cooling too.

The crystalline phase content in the as-prepared and calcined powders was determined by Xray diffraction (XRD) using a PANalytical XPERT-PRO diffractometer system, operating with the $\mathrm{Cu}$ $\mathrm{K} \alpha$ radiation $(\lambda=1.54059 \AA)$ and with $2 \theta$ varying from 10 to $60^{\circ}$ with a step of $0.026^{\circ}$. The experimental diffraction patterns were compared with standard maps (ICDD). The Match! Software from Crystal Impact was used to determine the percentages of the various phases and the unit cell parameters of the apatite phase. The crystallite size and strains were calculated using the Halder \& Wagner (H-W) method (Eq. 2) [40], [41]. This method considers both the size and strain effects on the 
XRD peak broadening and is relevant in case of Gaussian and Voigt profiles. The crystallite size and strain of the NPs are estimated using the $\mathrm{H}-\mathrm{W}$ equation:

$$
\left(\beta^{*} / d^{*}\right)^{2}=\frac{1}{\varepsilon}\left(\beta^{*} /\left(d^{*}\right)^{2}\right)+(\eta / 2)^{2} \quad \text { (Eq. 2) }
$$

where $\varepsilon$ is the parameter related to crystallite size, $\eta$ is the parameter linked to strain, $\beta^{*}=\beta \cos \theta / \lambda$ and $d^{*}=2 \sin \theta / \lambda$ are the reduced coordinates relying on the diffraction angle $\theta$ and the wavelength $\lambda$. The H-W plots are obtained by plotting $\left(\beta^{*} / d^{*}\right)^{2}$ versus $\beta^{*} /\left(d^{*}\right)^{2}$. The crystalline size, $\mathrm{D}$, is obtained from the slope (corrected by a factor 4/3) of the fit and the microstrain from the intercept (corrected by 2/5) [18]. The degree of crystallinity of the synthesized samples was determined using (Eq. 3) [42]:

$$
\% \text { Crystallinity }=\left(\frac{0.24}{F W H M}\right)^{3} \times 100(\text { Eq. 3) }
$$

where FWHM is the full width half maximum value for (002) peak in the XRD pattern of the apatite phase.

Chemical bonding identification was performed in the as-prepared and calcined powders using Infrared and Raman spectroscopies. IR spectra in the mid-infrared region $\left(400-4000 \mathrm{~cm}^{-1}\right)$ were obtained using a Spectrum Two 104462 IR spectrophotometer with a diamond ATR setup. For each measurement, $5 \mathrm{mg}$ of sample was deposited on a reflective solid (Tienta SpectRIM). Raman spectra were measured using a Renishaw inVia setup and a $532 \mathrm{~nm}$ laser.

Quantitative elemental analysis was carried out by Energy-Dispersive X-ray spectroscopy (EDX) with a JEOL JSM6400F device after deposition on a carbon-coated silicon substrate by evaporating a diluted aqueous suspension. Five zones were investigated for each powder and the average is presented in the following.

The powders were observed by Transmission Electron Microscopy (TEM) in order to estimate the crystal size and compare it with the crystallite size determined by XRD. TEM images were obtained using a JEOL JEM-2100F (at an accelerating voltage of $200 \mathrm{kV}$ ) after dropping a dilute suspension on carbon coated copper grids. 
The thermal stability of the powders was studied before sintering. ThermoGravimetric Analyses (TGA) of the powders were performed with a TA Instruments Discovery apparatus under an airflow rate of $25 \mathrm{~mL} / \mathrm{min}$ in a temperature range from $25^{\circ} \mathrm{C}$ to $800{ }^{\circ} \mathrm{C}$ and at a rate of $5{ }^{\circ} \mathrm{C} / \mathrm{min}$. Zeta potential ( $\zeta$-potential) and Dynamic Light Scattering (DLS) measurements were obtained with a Malvern Nano ZS instrument (DTS Nano V7.02) at $25^{\circ} \mathrm{C}$. DLS measurements were realized at $\mathrm{pH}=7$.

\section{Results and discussions}

\subsection{Mechanosynthesized powders}

\subsubsection{Structural analysis}

The X-ray diffractograms of HFA co-substituted with carbonate and lithium with the chemical formula $\mathrm{Ca}_{10-\mathrm{x}} \mathrm{Li}_{\mathrm{x}}\left(\mathrm{PO}_{4}\right)_{6-\mathrm{x}}\left(\mathrm{CO}_{3}\right)_{\mathrm{x}}(\mathrm{OH}) \mathrm{F}$ (with $\mathrm{x}$ ranging from 0 to 2.5 ) are shown in Fig. 1. The diffractograms reveal the presence of all the characteristic peaks of the HFA phase (ICDD 04-0162909) for $\mathrm{x} \leq 2$. Additional peaks assigned to unreacted $\mathrm{CaCO}_{3}(\mathrm{ICDD} 00-066-0867)$ and $\mathrm{Li}_{2} \mathrm{CO}_{3}$ (ICDD 04-010-7186) are also detected. The intensity of the apatite peaks decreases with increasing substitution rates. The peaks of apatite are more intense and narrower for $x<1.5$. At $x=2.5$, we notice the total absence of HFA peaks and the presence of unreacted calcite and $\mathrm{Li}_{2} \mathrm{CO}_{3}$ peaks (Fig. 1). For $\mathrm{x}=2.5$, the diffractogram shows the presence of an amorphous phase, in addition to the calcite phase, which could be the apatite phase.

The apatite cell parameters and the relative amount of the apatite, $\mathrm{CaCO}_{3}$ and $\mathrm{Li}_{2} \mathrm{CO}_{3}$ phases, crystallite size, crystallinity and lattice strain are shown in Table 1. Increasing the substitution rate results in a decrease of the $a$ parameter and an increase of the $c$ parameter. The lengths of the carbonoxygen bonds $\left(1.3 \AA\right.$ ) are shorter than those of the phosphorus-oxygen bonds $(1.5 \AA)$ and the $\mathrm{Li}^{+}$radius $\left(\mathrm{r}\left(\mathrm{Li}^{+}\right)=0.76 \AA\right.$ when 6 coordinated $)$ is smaller than the $\mathrm{Ca}^{2+}$ one $\left(\mathrm{r}\left(\mathrm{Ca}^{2+}\right)=1 \AA\right.$ when 6 coordinated $)$. Consequently, the decrease of the $a$ lattice constant can result from the substitution of phosphate 
$\left(\mathrm{PO}_{4}{ }^{3-}\right)$ groups and $\mathrm{Ca}^{2+}$ ions by smaller $\mathrm{CO}_{3}{ }^{2-}$ and $\mathrm{Li}^{+}$ions respectively [43]. However, Mayer et al [28] observed that a small $\mathrm{Li}^{+}$incorporation did not modify the lattice parameters and that small $\mathrm{Li}^{+}$ incorporation increased with the carbonate substitution rate. The increase of the $c$ parameter is consecutive to the $a$ axis contraction due to the accommodation of the apatite structure to maintain $c / a$ constant [44]. At least, the lattice parameter evolution demonstrates that $\mathrm{CO}_{3}{ }^{2-}$ ions are incorporated into the crystal lattice of HFA. In HA, the substitution of $\mathrm{PO}_{4}{ }^{3-}$ by $\mathrm{CO}_{3}{ }^{2-}$ groups results in a decrease of the $a$ parameter $(-0.4 \%)$ and a slight increase of the $c$ parameter $(+0.06 \%)$, in the case of a B-type substitution only [45], [46]. Given the evolution of the cell parameters, it is reasonable to think that the substitution in our HFA is of B-type. The contraction along the $a$-axis increases with the substitution rate.

The crystallinity of the apatite phase gradually decreased from 49 to $11 \%$ with increasing lithium and carbonate content (Fig.1 and Table 1), which is in agreement with previous works [15], [44]. The apatite is non-stoichiometric. The lattice strain remains the same, whatever the substitution and is around 0.40 which is in agreement with Badran et al [15].

The amount of the apatite phase are divided by 2 as the substitution rate increases from $x=0$ to 2. The crystallite size is of the order of $18 \mathrm{~nm}$, independently of the substitution rate. Deymier et al. [47] have demonstrated by modelling how the carbonate content controlled the apatite crystal growth and favored nanometric apatite crystallites. They obtained a rapid drop off at low carbonate content then followed by a plateau, plateau observed in our case. 


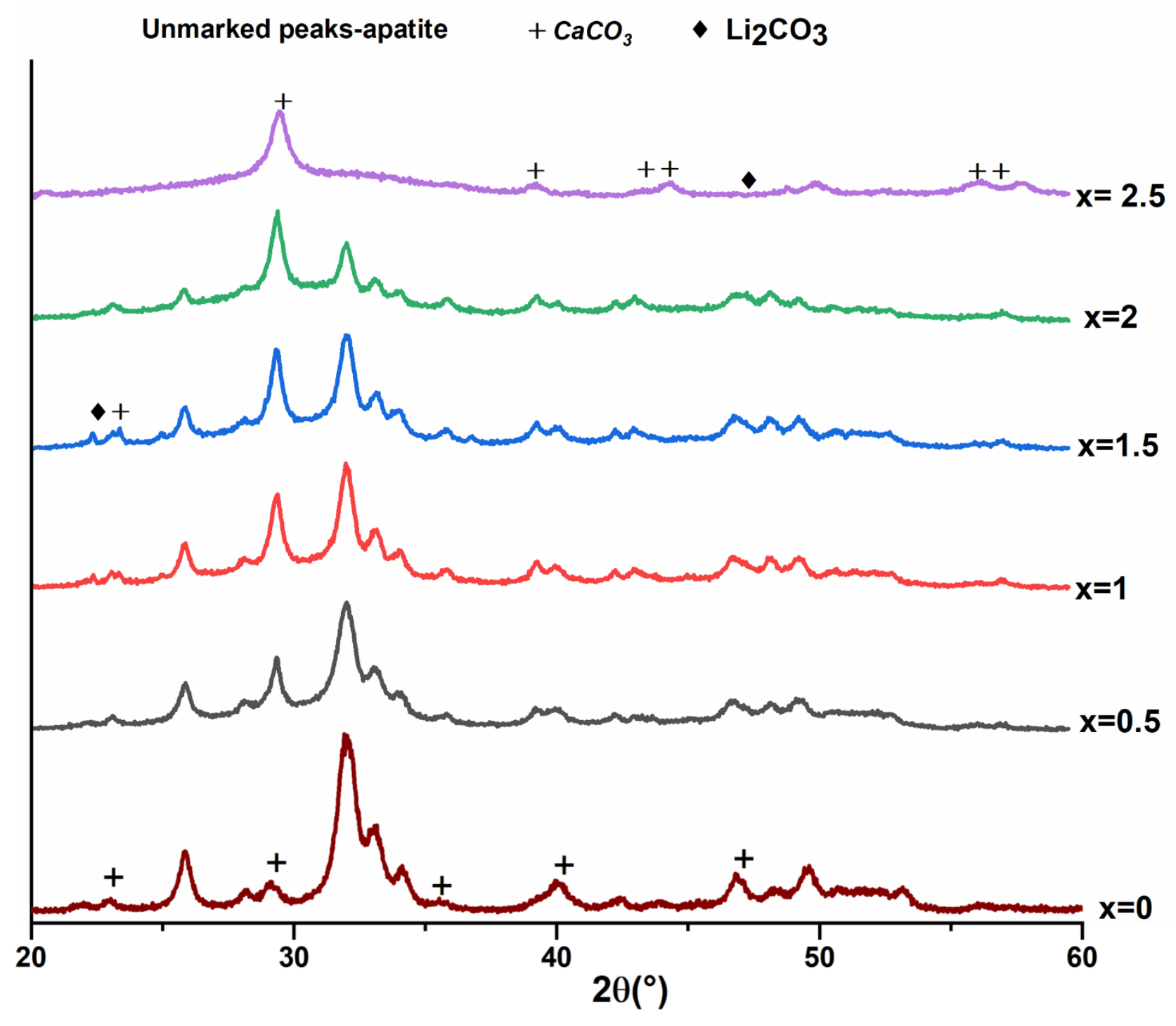

Fig. 1. $\mathrm{X}$-ray diffractograms of $\mathrm{Ca}_{10-\mathrm{x}} \mathrm{Li}_{\mathrm{x}}\left(\mathrm{PO}_{4}\right)_{6-\mathrm{x}}\left(\mathrm{CO}_{3}\right)_{\mathrm{x}}(\mathrm{OH}) \mathrm{F}$ powders with $0 \leq \mathrm{x} \leq 2.5$

Table 1. Relative amount of apatite, calcite and $\mathrm{Li}_{2} \mathrm{CO}_{3}$. Hexagonal cell parameters for the $\mathrm{Ca}_{10-\mathrm{x}} \mathrm{Li}_{\mathrm{x}}\left(\mathrm{PO}_{4}\right)_{6-\mathrm{x}}\left(\mathrm{CO}_{3}\right)_{\mathrm{x}}(\mathrm{OH}) \mathrm{F}$ powders, crystallite size and strains of the apatite phase obtained by the Halder \& Wagner method, and crystallinity (\%).

\begin{tabular}{|c|c|c|c|c|c|c|c|c|}
\hline $\begin{array}{c}\text { Substitution } \\
\text { rate }(\mathbf{x})\end{array}$ & $\mathbf{a}(\AA)$ & c $(\AA)$ & $\begin{array}{l}\text { Apatite } \\
\text { (wt. \%) } \\
\pm 0.1 \%\end{array}$ & $\begin{array}{l}\text { Calcite } \\
\text { (wt. \%) } \\
\pm 0.1 \%\end{array}$ & $\begin{array}{l}\mathrm{Li}_{2} \mathrm{CO}_{3} \\
\text { (wt. \%) } \\
\pm 0.1 \%\end{array}$ & $\begin{array}{r}D_{\text {XRD }} \\
\pm 2 \mathrm{~nm}\end{array}$ & $\begin{array}{l}\text { Lattice } \\
\text { strain }\end{array}$ & \% Crystallinity \\
\hline $\mathrm{x}=\mathbf{0}$ & $9.372(2)$ & $6.893(2)$ & 99.6 & 0.4 & - & 19 & 0.36 & 49 \\
\hline
\end{tabular}




\begin{tabular}{|c|c|c|c|c|c|c|c|c|}
\hline $\mathbf{x = 0 . 5}$ & $9.356(4)$ & $6.901(3)$ & 94.9 & 5.1 & - & $\mathbf{1 8}$ & $\mathbf{0 . 4 0}$ & $\mathbf{4 8}$ \\
\hline $\mathbf{x = 1}$ & $9.353(5)$ & $6.907(1)$ & 89.9 & 7.5 & 1.6 & $\mathbf{1 7}$ & $\mathbf{0 . 4 2}$ & $\mathbf{3 0}$ \\
\hline $\mathbf{x = 1 . 5}$ & $9.347(1)$ & $6.910(7)$ & 84.3 & 11.4 & 4.3 & $\mathbf{1 9}$ & $\mathbf{0 . 3 6}$ & $\mathbf{1 0}$ \\
\hline $\mathbf{x = 2}$ & $9.336(3)$ & $6.914(5)$ & 51.8 & 42.3 & 5.9 & $\mathbf{1 7}$ & $\mathbf{0 . 4 2}$ & $\mathbf{1 1}$ \\
\hline
\end{tabular}

The IR spectra of the as-prepared samples are shown in Fig. 2. The broad absorption bands in the $2500-3700 \mathrm{~cm}^{-1}$ range are assigned to the O-H stretching vibration [15], [16]. The IR spectra show all the bands associated to the phosphate groups $\left(\mathrm{PO}_{4}\right)^{3-}$ in the apatite environment: asymmetric stretching (v3) located around 1090 and $1041 \mathrm{~cm}^{-1}$, symmetric stretching (v1) around $963 \mathrm{~cm}^{-1}$, symmetric bending (v4) located between 600 and $560 \mathrm{~cm}^{-1}$ and asymmetric bending (v2) around $473 \mathrm{~cm}^{-1}$ [13]. The appearance of a new low intensity band at about $745 \mathrm{~cm}^{-1}$ is assigned to F-OH vibration [16], [20]. Vibration bands of the carbonate groups appear around $842 \mathrm{~cm}^{-1}$ and are assigned to the off-plane bending mode $v 2$ (in singlet form) and the two elongation antisymmetric modes $v 3$ (in doublet form) are observed around $1390 \mathrm{~cm}^{-1}$ and $1415 \mathrm{~cm}^{-1}$ [36], [37]. The increase in the substitution rate leads to an increase in the intensities of the $\mathrm{CO}_{3}{ }^{2-}$ absorption bands while those of the phosphate groups decrease and become poorly defined. The $\mathrm{CO}_{3}{ }^{2-}$ absorption bands are observed in the $\mathrm{x}=0$ powder too. The $\mathrm{CO}_{3}{ }^{2-}$ groups result from either the presence of impurities $\left(\mathrm{CaCO}_{3}\right)$ or $\mathrm{CO}_{3}{ }^{2-}$ substitution in the apatite structure. Coreño et al [22] have showed that HA obtained by mechanosynthesis using $\mathrm{CaCO}_{3}$ as precursor of calcium cannot be considered as a non-substituted HA. Spectra of the substituted samples for $\mathrm{x} \geq 1$ show also the appearance of new absorption band around $426 \mathrm{~cm}^{-1}$ attributed to the vibration mode of the Li-O bond (Fig. 2b). This is in accordance with Brooker et al. [48] who observed the vibration band of the $\mathrm{Li}-\mathrm{O}$ bond at about $428 \mathrm{~cm}^{-1}$ in a carbonate of lithium. 
(a)

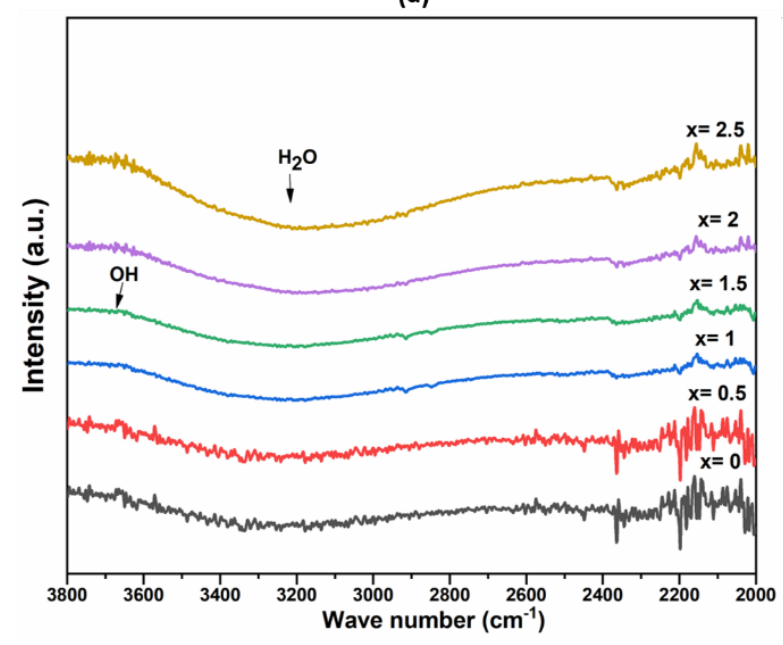

(b)

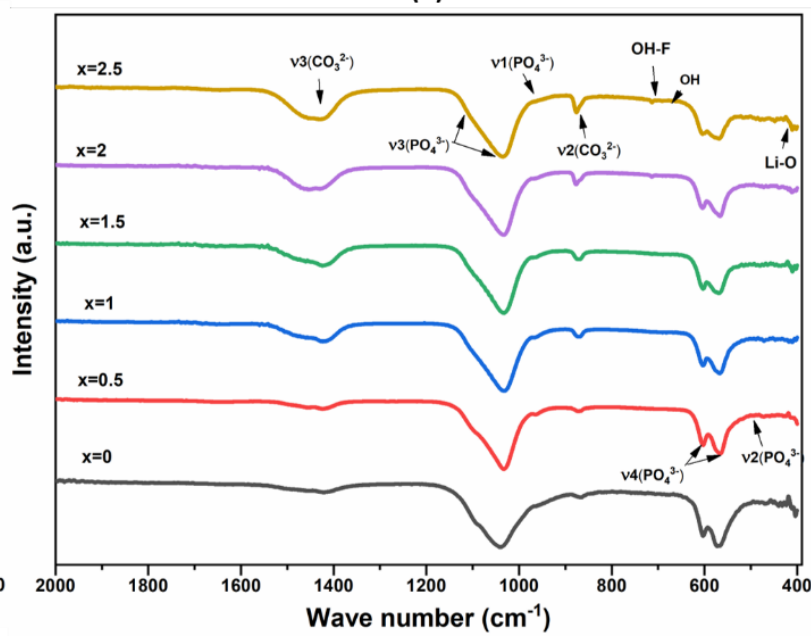

Fig. 2. IR spectra of $\mathrm{Ca}_{10-\mathrm{x}} \mathrm{Li}_{\mathrm{x}}\left(\mathrm{PO}_{4}\right)_{6-\mathrm{x}}\left(\mathrm{CO}_{3}\right)_{\mathrm{x}}(\mathrm{OH}) \mathrm{F}$ powders with $0 \leq \mathrm{x} \leq 2.5$, (a) IR spectra in the $3800-2000 \mathrm{~cm}^{-1}$ region, (b) IR spectra in the $2000-400 \mathrm{~cm}^{-1}$ region

Fig. 3a shows the Raman spectra of the powders obtained after mechanosynthesis. The observed bands match those reported by Badran et al. [15], Antonakos et al. [49], and Rehman et al. [50]. The most intense band is assigned to the symmetric stretching of the $\mathrm{PO}_{4}{ }^{3-}$ mode $(v 1)$ at around $962 \mathrm{~cm}^{-1}$. The peaks located at 429 and $451 \mathrm{~cm}^{-1}$ are assigned to the symmetric bending (v2), the one at $1072 \mathrm{~cm}^{-1}$ to the $v 3$ asymmetric stretching and those at 585 and $608 \mathrm{~cm}^{-1}$ to asymmetric bending (v4) [16]. The very low intensity peaks observed around $387 \mathrm{~cm}^{-1}$ correspond to the elongation mode of the $\mathrm{Ca}-\mathrm{OH}$ bond (v3) [51], [52]. Fig. 3a also shows the appearance of peaks attributed to carbonate groups around $1070 \mathrm{~cm}^{-1}(\mathrm{v} 1)$, characteristic of $\mathrm{PO}_{4}{ }^{3-}$ group substitution and around $282 \mathrm{~cm}^{-1}, 714 \mathrm{~cm}^{-1}$ and $1080 \mathrm{~cm}^{-1}$, typical of calcite [53]. Increasing the substitution rate in the apatite structure leads to a decrease in the intensity of the phosphate vibration bands with respect to those of the carbonate groups [50]. A displacement of the characteristic peak $(v 1)$ of the $\mathrm{PO}_{4}{ }^{3-}$ groups to lower wave numbers is also detected for $\mathrm{x}>1.5$ (Fig. 3b). Penel et al [52] observed that the substitution of $\mathrm{PO}_{4}{ }^{3-}$ ions by carbonate ions induces a slight shift towards the low frequencies in the case of B-carbonate apatite $\left(961 \mathrm{~cm}^{-1}\right)$ compared to pure hydroxyfluorapatite HFA $\left(964 \mathrm{~cm}^{-1}\right)$. This shift is unchanged whatever the carbonate substitution rate. They showed also an increase of the widths of all carbonated apatite peaks as the 
crystallites become smaller and more distorted when the carbonate amount increased. Thanks to the changes observed in both peak width and peak frequency of the phosphate and carbonate vibration modes, we can reasonably suppose that the substitution is a B-type. A new peak around $1000 \mathrm{~cm}^{-1}$ appears for $\mathrm{x} \geq 1.5$ (Fig. 3a). This band can be assigned to the $\mathrm{HPO}_{4}{ }^{2-}$ group or attributed to the lithium carbonate vibration mode [48]. Unfortunately, the presence of $\mathrm{HPO}_{4}{ }^{2-}$ group cannot be confirmed for sure because the IR bands of $\mathrm{HPO}_{4}{ }^{2-}$ group can be masked by the carbonate band at $870 \mathrm{~cm}^{-1}$ or the phosphate band $v 4$.

(a)

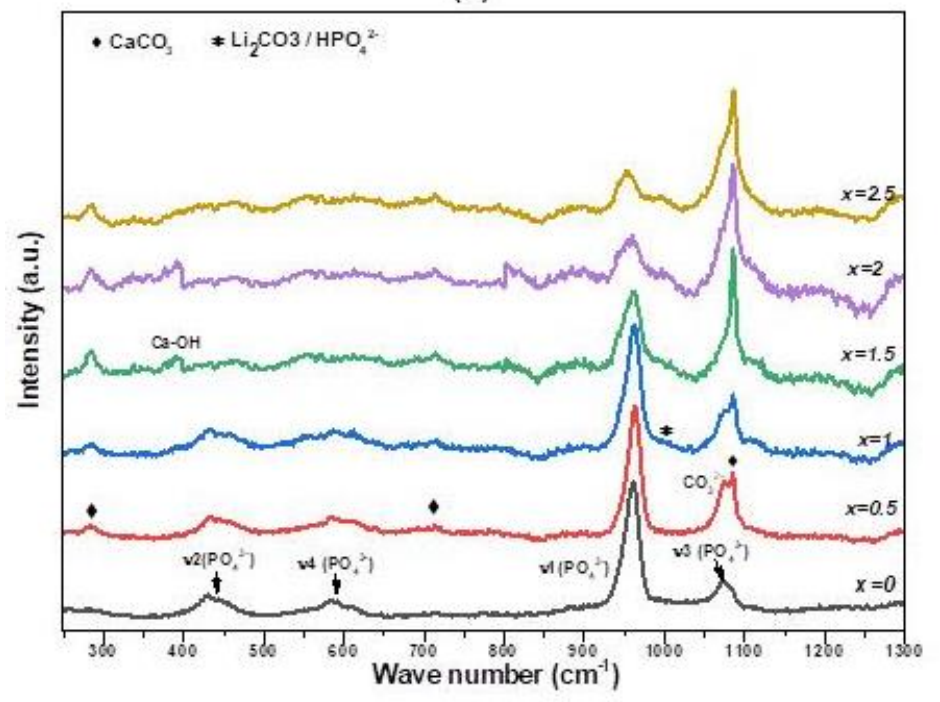

(b)

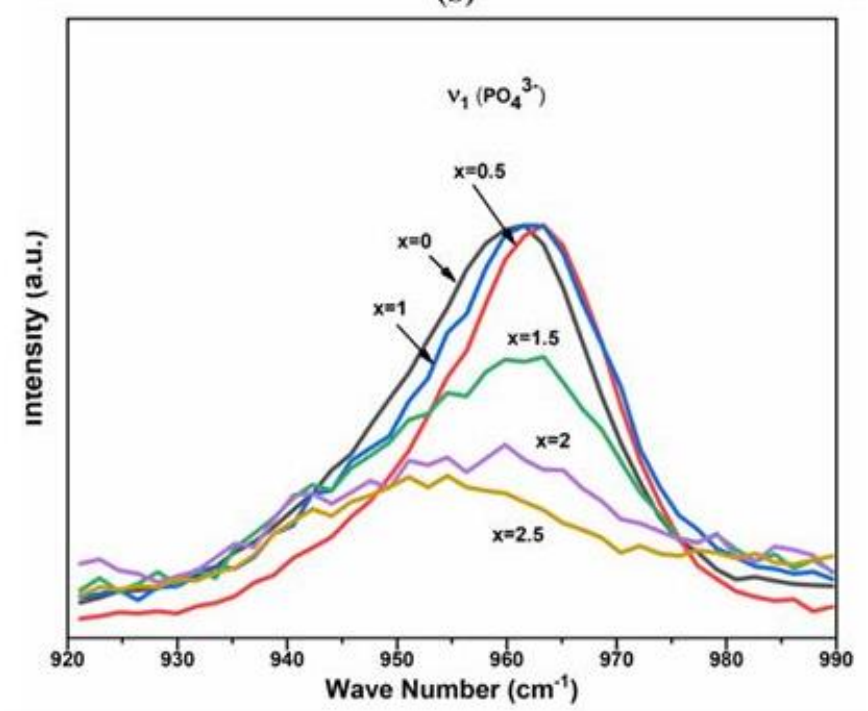

Fig. 3. (a) Raman spectra of $\mathrm{Ca}_{10-\mathrm{x}} \mathrm{Li}_{\mathrm{x}}\left(\mathrm{PO}_{4}\right)_{6-\mathrm{x}}\left(\mathrm{CO}_{3}\right)_{\mathrm{x}}(\mathrm{OH}) \mathrm{F}$ powders with $0 \leq \mathrm{x} \leq 2.5$, (b) the symmetric stretching of the $\mathrm{PO}_{4}{ }^{3-}$ mode $(v 1)$ of powders

\subsubsection{Thermal analysis}

Thermogravimetric analyses of the as-synthesized powders are presented in Fig. 4. They were performed to study the thermal stability of the samples prepared with different substitution rates. The overall losses are $10.6 \%(x=0), 15.5 \%(x=0.5), 17 \%(x=1)$ and $16 \%(x=1.5)$. All the thermograms (for $\mathrm{x}>0$ ) have at least four mass losses. Their magnitudes depend on the substitution rate. Physisorbed water was eliminated below $100^{\circ} \mathrm{C}$. The first mass loss observed at $100-200^{\circ} \mathrm{C}$ corresponds to the 
departure of chemisorbed water and is about $5 \%(x=0), 6 \%(x=0.5), 4 \%(x=1)$ and $3 \%(x=1.5)$. The second loss, of the order of $4 \%(x=0), 5.5 \%(x=0.5), 8 \%(x=1)$ and $7 \%(x=1.5)$ located around 200$500^{\circ} \mathrm{C}$ is attributed to the departure of lattice water, residual $\mathrm{NH}_{4}{ }^{+}$and $\mathrm{HPO}_{4}{ }^{2-}$ species [54]-[56]. Most of the lattice water is related to carbonate ions [54]. The third mass loss observed around $500-750^{\circ} \mathrm{C}$ depending on $\mathrm{x}$ is of the order of $1.6 \%(\mathrm{x}=0), 4 \%(\mathrm{x}=0.5), 5.0 \%(\mathrm{x}=1)$ and $5.5 \%(\mathrm{x}=1.5)$. It is tentatively assigned to the departure of carbonates and the release of $\mathrm{CO}_{2}$ [57], [58]. Given that the decomposition temperatures of calcite and lithium carbonate (present as secondary phase in the samples) are above $625^{\circ} \mathrm{C}[59]$ and $730^{\circ} \mathrm{C}$ respectively, the release of $\mathrm{CO}_{2}$ at a lower temperature correspond to the apatite decarbonation. Substitution of fluoride ions in A sites lowers the temperature of decarbonation of Btype apatite down to $500^{\circ} \mathrm{C}$ [60], [61]. The decarbonation temperature is strongly dependent on the chemical composition. Zyman et al. [61] suggested that the removal of carbonate from the apatite structure occurs at temperatures between 550 and $750{ }^{\circ} \mathrm{C}$ depending on the carbonation rate. The mass loss is theoretically about $3.1 \%(x=0.5), 6.4 \%(x=1)$ and $9.9 \%(x=1.5)$. Considering the mass loss differences between experiment and theory, the decarbonation process can be considered partial for the two highest substitution rates or the substitution rate is not as high as expected in the asmechanosynthesized powders. Above, the mass loss can be explained by the partial decomposition of HAF apatite and/or secondary phases [62], [63].
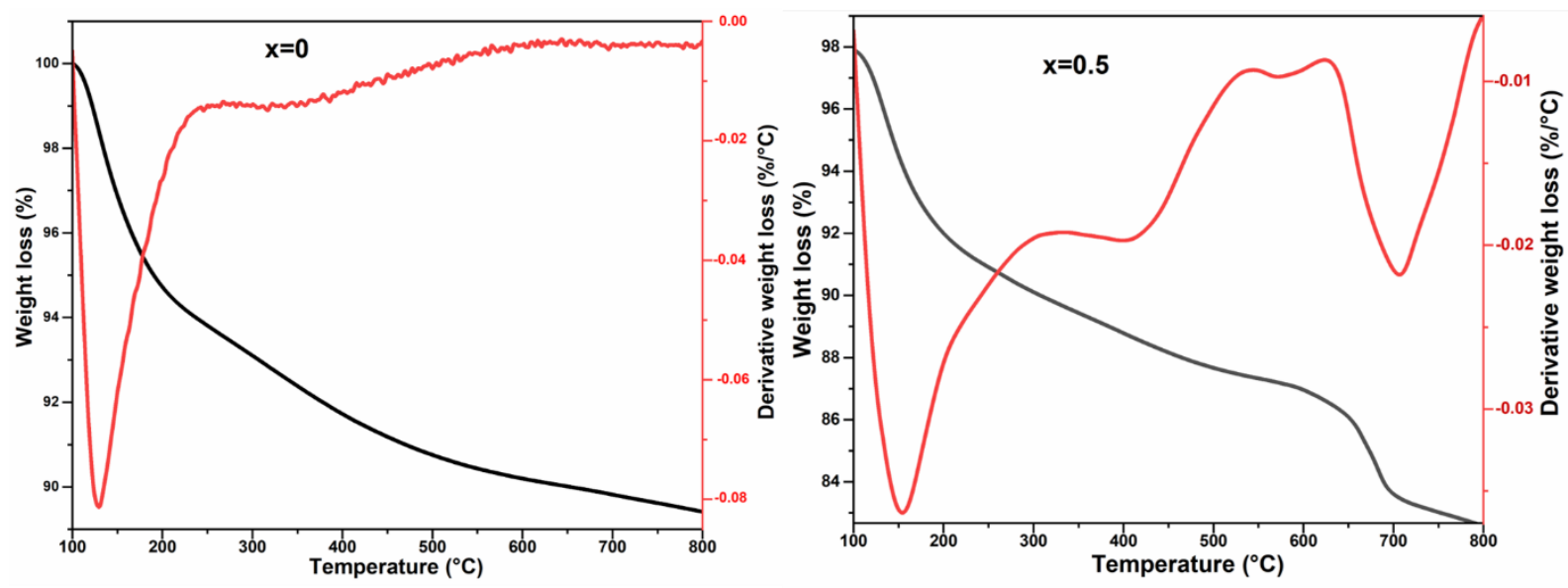

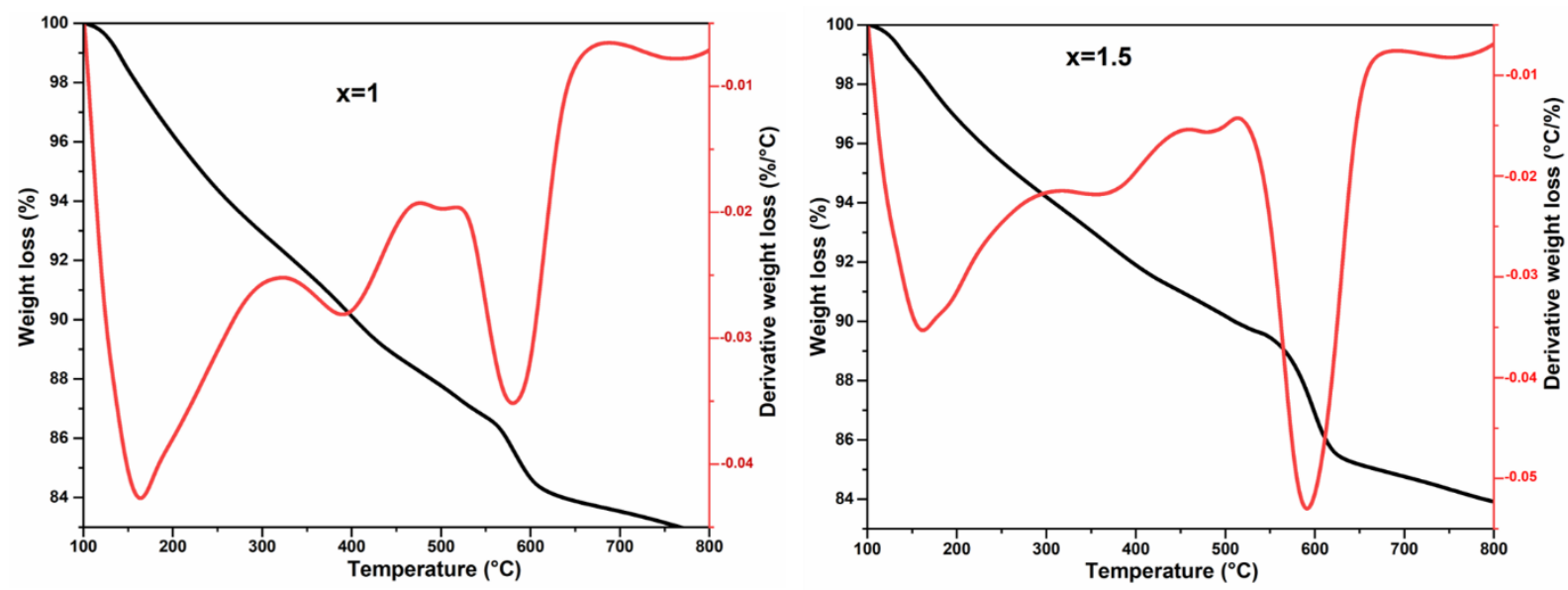

Fig. 4. TGA and DTG curves of $\mathrm{Ca}_{10-\mathrm{x}} \mathrm{Li}_{\mathrm{x}}\left(\mathrm{PO}_{4}\right)_{6-\mathrm{x}}\left(\mathrm{CO}_{3}\right)_{\mathrm{x}}(\mathrm{OH}) \mathrm{F}$ powders with $0 \leq \mathrm{x} \leq 1.5$

\subsection{Calcined powders}

Since substituted HAF starts to decompose at temperatures close to $500^{\circ} \mathrm{C}$, we have chosen to limit the duration of calcination to $1 \mathrm{~h}$ at $500^{\circ} \mathrm{C}$ to improve the crystallinity of the powder.

\subsubsection{Structural analysis}

The XRD diffractograms of the powders calcined at $500^{\circ} \mathrm{C}$ in air for 1 hour are shown in Fig. 5 and the results of the structural analyses are presented in Table 2. The apatite lines are more intense and thinner than in Fig. 1. The diffractograms also show the appearance of additional peaks for substitution rates larger than 1 . Calcium carbonate (ICDD card $\mathrm{n}^{\circ} 00-066-0867$ ) is observed for $\mathrm{x} \geq 1$ whereas it was present in all the as-mechanosynthesized powders. Its proportion is also diminished (6\% against $42 \%$ for $x=2)$. The amount of calcite increases drastically for $x=2.5$. Lithium phosphate $\left(\mathrm{Li}_{3} \mathrm{PO}_{4}\right)(\mathrm{ICDD}$ card $\left.\mathrm{n}^{\circ} 00-025-1030\right)$ appears from $\mathrm{x}=1.5$, in proportions close to those of the lithium-based compound $\left(\mathrm{Li}_{2} \mathrm{CO}_{3}\right)$ detected in the as-mechanosynthesized powders. This is probably related to the saturation of the solid solution for $x \geq 1$ [15]. However, the drastic decrease of the lithium carbonate amount tends to prove that a large part has been incorporated in the apatite structure. Then, the substituted phosphate groups react with $\mathrm{Li}^{+}$to form $\mathrm{Li}_{3} \mathrm{PO}_{4}$. For $\mathrm{x}=1$, the disappearance of lithium carbonate and the absence 
of lithium phosphate tend to prove that $\mathrm{Li}^{+}$has been incorporated in the apatite structure after the annealing at $500^{\circ} \mathrm{C}$.

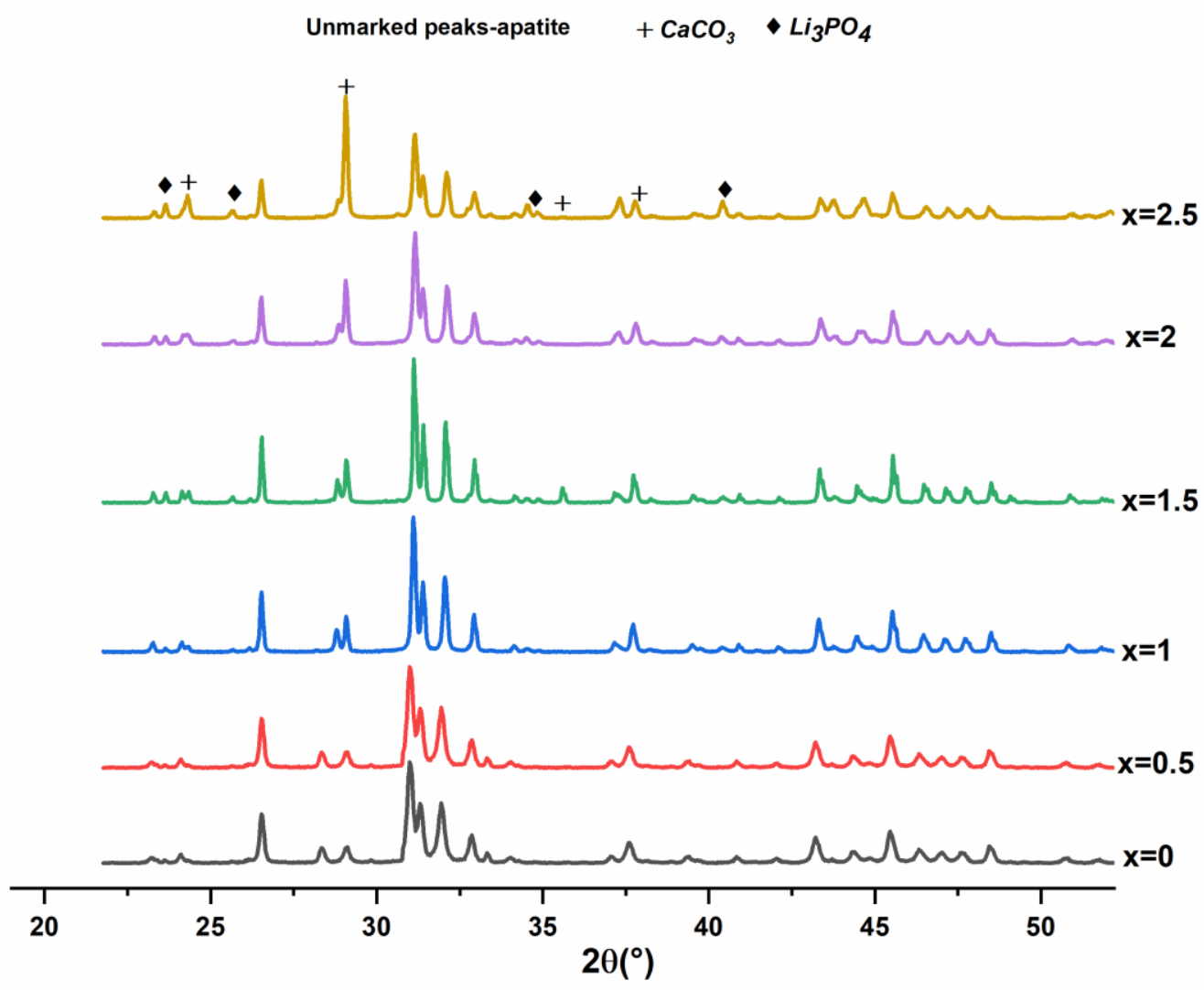

Fig. 5. X-ray diffractograms of $\mathrm{Ca}_{10-\mathrm{x}} \mathrm{Li}_{\mathrm{x}}\left(\mathrm{PO}_{4}\right)_{6-\mathrm{x}}\left(\mathrm{CO}_{3}\right)_{\mathrm{x}}(\mathrm{OH}) \mathrm{F}$ powders with $0 \leq \mathrm{x} \leq 2.5$ calcined $1 \mathrm{~h}$ at $500^{\circ} \mathrm{C}$ under air

Table 2 indicates the variation of the cell parameters as a function of the substitution rate. The decrease of $a$ and the increase of $c$ as a function of $\mathrm{x}$, as observed for untreated samples, is compatible with the preservation of the carbonated B-type apatite. However, the new cell parameter values (higher for $a$ and lower for $c$ than for untreated samples) confirm that decarbonation has occurred during the annealing at $500{ }^{\circ} \mathrm{C}$. The crystallite size determined by the Halder \& Wagner method $\left(\mathrm{D}_{\mathrm{XRD}}\right)$ for each composition was between 31 and $48 \mathrm{~nm}$. The crystallite size of the calcined powders is one and a half to two and a half times greater than that of the as-mechanosynthesized ones. The crystallite size is 
around $45 \mathrm{~nm}$ for all the carbonated apatites and of about $30 \mathrm{~nm}$ for $\mathrm{x}=0$. For the highest substitution rates, the enhanced diffusion ensured by non-stoichiometry is annihilated by the decarbonation which starts earlier. After calcination, the crystallinity of the powders is improved. The value of the crystallinity is between 84 and $42 \%$ for $\mathrm{x}$ varying from 0 to 2 . For $\mathrm{x}$ greater than 0 , the strain value remains almost unchanged (around 0.10-0.20). With the increase of the substitution rate of lithium and carbonates, in both anionic and cationic sites, the variation of lattice deformation is low. This can be explained by the fact that the sizes of lithium and carbonate are smaller than the calcium and phosphate groups, so the lattice strain varies slightly.

Table 2. Relative amount of apatite, calcite and $\mathrm{Li}_{3} \mathrm{PO}_{4}$. Hexagonal cell parameters for the $\mathrm{Ca}_{10-\mathrm{x}} \mathrm{Li}_{\mathrm{x}}\left(\mathrm{PO}_{4}\right)_{6-\mathrm{x}}\left(\mathrm{CO}_{3}\right)_{\mathrm{x}}(\mathrm{OH}) \mathrm{F}$ powders calcined $1 \mathrm{~h}$ at $500^{\circ} \mathrm{C}$ under air, crystallite size and strains of the apatite phase obtained by Halder \& Wagner method, and crystallinity (\%).

\begin{tabular}{|c|c|c|c|c|c|c|c|c|}
\hline $\begin{array}{l}\text { Substitution } \\
\text { rate }(x)\end{array}$ & $\mathbf{a}(\AA)$ & c $(\AA)$ & $\begin{array}{l}\text { Apatite } \\
\text { (wt. \%) } \\
\pm 0.1 \%\end{array}$ & $\begin{array}{l}\mathrm{CaCO}_{3} \\
(\text { wt. \%) } \\
\pm 0.1 \%\end{array}$ & $\begin{array}{l}\mathrm{Li}_{3} \mathrm{PO}_{4} \\
\text { (wt. \%) } \\
\pm 0.1 \%\end{array}$ & $\begin{aligned} & D_{X R D} \\
\pm & 2 \mathrm{~nm}\end{aligned}$ & $\begin{array}{l}\text { Lattice } \\
\text { strain }\end{array}$ & $\begin{array}{c}\% \\
\text { Crystallinity }\end{array}$ \\
\hline $\mathrm{x}=\mathbf{0}$ & $9.393(1)$ & $6.882(7)$ & 100.0 & 0.0 & 0.0 & 31 & 0.27 & 84 \\
\hline $\mathrm{x}=0.5$ & $9.392(2)$ & $6.883(8)$ & 100.0 & 0.0 & 0.0 & 44 & 0.07 & 72 \\
\hline$x=1$ & $9.391(3)$ & $6.889(2)$ & 95.4 & 4.6 & 0.0 & 48 & 0.11 & 79 \\
\hline$x=1.5$ & $9.376(1)$ & $6.889(9)$ & 91.4 & 5.4 & 3.2 & 42 & 0.18 & 51 \\
\hline$x=2$ & $9.368(1)$ & $6.894(6)$ & 89.9 & 6.0 & 4.1 & 47 & 0.14 & 42 \\
\hline$x=2.5$ & $9.371(1)$ & $6.895(2)$ & 59.1 & 31.8 & 9.1 & 46 & 0.18 & 31 \\
\hline
\end{tabular}

The infrared absorption (IR) spectra of the calcined powders are shown in Fig. 6. In comparison with untreated powders (Fig. 2), the broad bands between 2500 and $3700 \mathrm{~cm}^{-1}$, attributed to water molecules adsorbed on surfaces, disappear. After calcination, the three bands of phosphate (v1, v3 and v4) and the two bands of carbonate (v2 and v3), as well as that of the OH-F bonds located around 
$745 \mathrm{~cm}^{-1}$ have decreased in width. The frequency values of the carbonate group bands (in the doublet form) indicate that the carbonation is still of B-type [64].

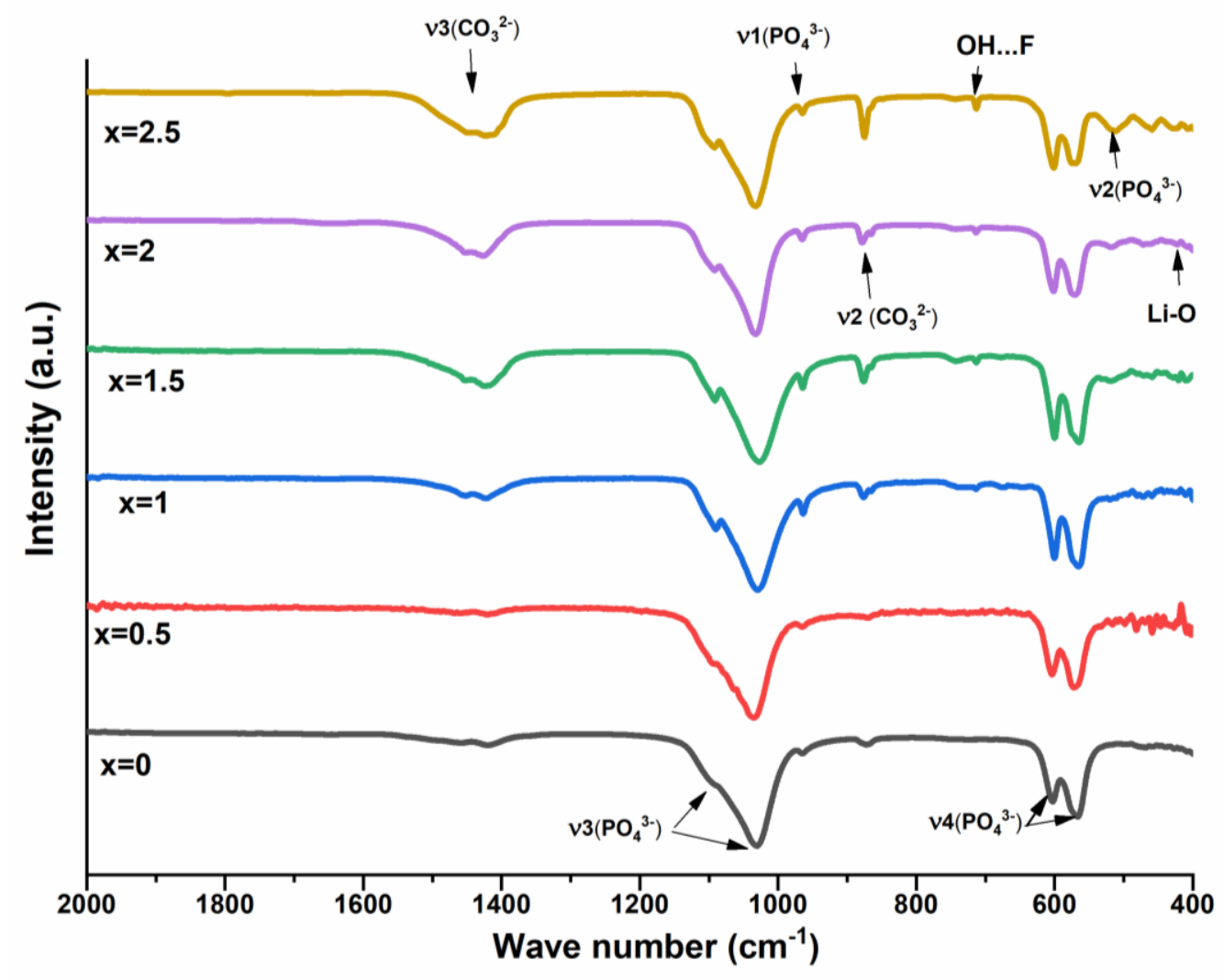

Fig. 6. IR spectra of $\mathrm{Ca}_{10-\mathrm{x}} \mathrm{Li}_{\mathrm{x}}\left(\mathrm{PO}_{4}\right)_{6-\mathrm{x}}\left(\mathrm{CO}_{3}\right)_{\mathrm{x}}(\mathrm{OH}) \mathrm{F}$ powder with $0 \leq \mathrm{x} \leq 2.5$, calcined for one hour at $500^{\circ} \mathrm{C}$ under air

The Raman spectra in Fig. 7 show almost the same characteristic bands observed in Fig. 3 before annealing. The band at around $1000 \mathrm{~cm}^{-1}$ assigned to $\mathrm{HPO}^{2-}$ and/or a lithium carbonate vibration mode has disappeared. Indeed, $\mathrm{HPO}^{2-}$ reacts with $\mathrm{CO}_{3}{ }^{2-}$ in $\mathrm{B}$-sites above $400^{\circ} \mathrm{C}$ [52] and the XRD results have shown the absence of lithium carbonate in the calcined powders. The band of the phosphate group (v1) is more intense and thinner from $x=1$. The relative intensities of the phosphate and carbonate groups (at $960 \mathrm{~cm}^{-1}$ and $1070 \mathrm{~cm}^{-1}$ respectively) have evolved, suggesting that a partial decarbonation has occurred [15], [44]. The relative intensities of the phosphate and carbonate groups 
(at $960 \mathrm{~cm}^{-1}$ and $1085 \mathrm{~cm}^{-1}$ respectively) reverse from $\mathrm{x}=1.5$, in good agreement with the decrease of calcite amount in the samples.

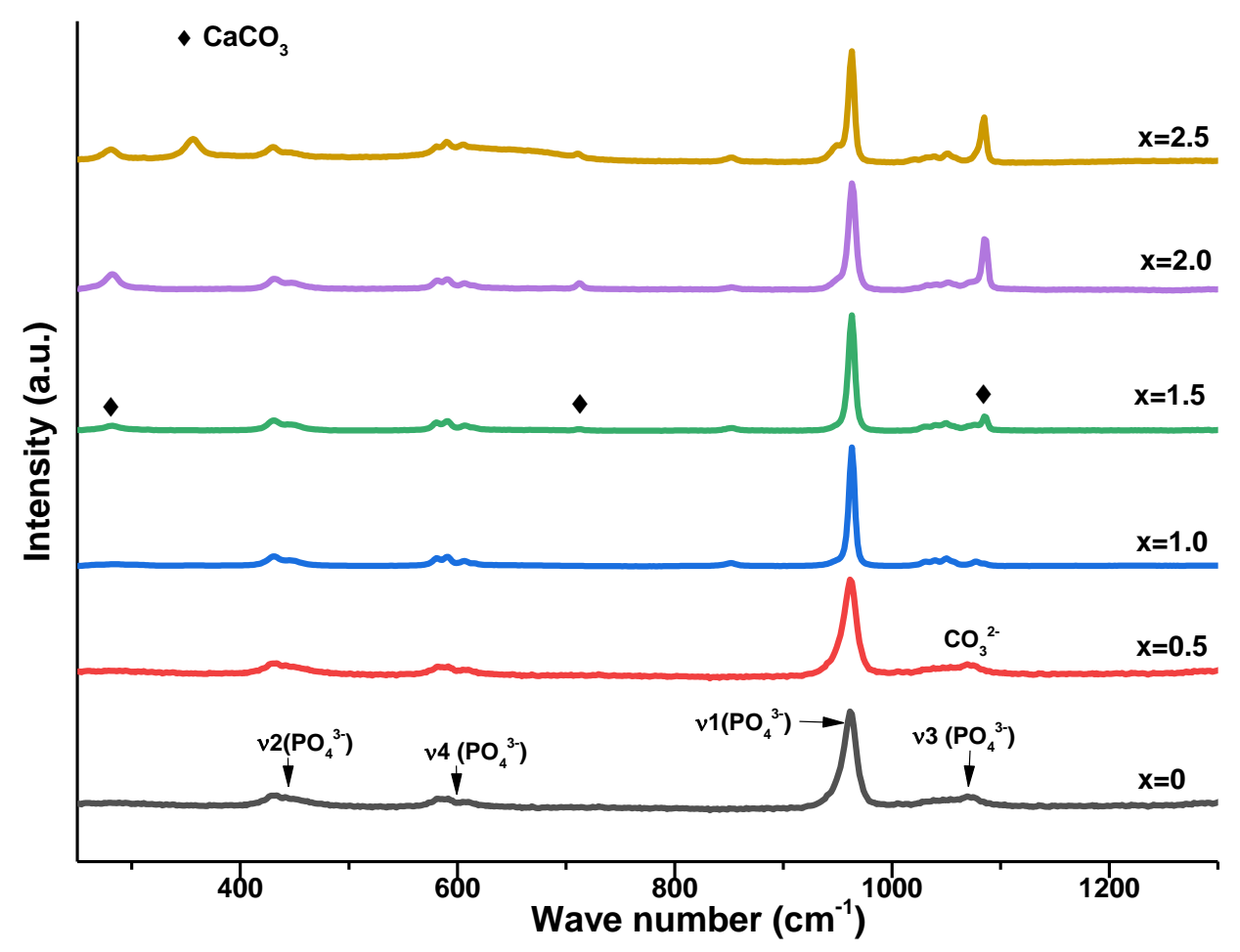

Fig. 7. The Raman spectra of all $\mathrm{Ca}_{10-\mathrm{x}} \mathrm{Li}_{\mathrm{x}}\left(\mathrm{PO}_{4}\right)_{6-\mathrm{x}}\left(\mathrm{CO}_{3}\right)_{\mathrm{x}}(\mathrm{OH}) \mathrm{F}$ samples calcined $1 \mathrm{~h}$ at $500^{\circ} \mathrm{C}$ under air

\subsubsection{Chemical and morphological study}

A chemical analysis was performed for the $x=0$ and $x=1$ samples to determine the calcium/phosphorus atomic ratio and the lithium and carbonate substitutions. Elemental analysis by EDX reveals the presence of calcium, phosphorus, oxygen and fluorine for substituted and unsubstituted apatite (Table 3). It should be noted that the steel jars and balls used for grinding are sources of iron contamination of the powder. A low contamination (between 0.3 and $0.4 \%$ of $\mathrm{Fe}$ ) resulting from the shocks between the jar wall, the powder and the balls was detected [16]. Detection of lithium and carbon by EDX is of course difficult. A very good agreement between the atomic percentage of the different elements determined from these spectra and those introduced via the initial 
powders was observed (see Table S1). The calcium to phosphorus ratio $(\mathrm{Ca} / \mathrm{P})$ increases with the substitution of pairs $\left(\mathrm{Ca}^{2+}, \mathrm{PO}_{4}{ }^{3-}\right)$ by $\left(\mathrm{Li}^{+}, \mathrm{CO}_{3}{ }^{2-}\right)$, as expected. This increase is compatible with overstoichiometric B-type carbonated HFA [65]. However, for the untreated sample with $x=0$, it can be assumed that at the beginning of the reaction an amorphous calcium phosphate is formed, with a $\mathrm{Ca} / \mathrm{P}$ ratio close to $1.5[66]$.

Table 3. Atomic percentages of the chemical elements present in untreated and calcined at $500^{\circ} \mathrm{C}$ of $\mathrm{Ca}_{10-\mathrm{x}} \mathrm{Li}_{\mathrm{x}}\left(\mathrm{PO}_{4}\right)_{6-\mathrm{x}}\left(\mathrm{CO}_{3}\right)_{\mathrm{x}}(\mathrm{OH}) \mathrm{F}$ powders for $\mathrm{x}=0$ and 1 determined by EDX

\begin{tabular}{|c|c|c|c|c|}
\hline & \multicolumn{2}{|c|}{ Untreated sample } & \multicolumn{2}{c|}{ Calcined sample at 500 ${ }^{\circ}$} \\
\hline Substitution rate & $\mathbf{x = 0}$ & $\mathbf{x = 1 . 0}$ & $\mathbf{x = 0}$ & $\mathbf{x = 1 . 0}$ \\
\hline Oxygen & $57.1(5)$ & $64.2(3)$ & $61.6(4)$ & $61.6(1)$ \\
\hline Fluorine & $3.5(2)$ & $2.4(4)$ & $2.9(1)$ & $2.6(4)$ \\
\hline Phosphorus & $14.5(2)$ & $11.9(2)$ & $12.9(2)$ & $12.3(3)$ \\
\hline Calcium & $22.3(4)$ & $21.8(4)$ & $22.1(3)$ & $21.7(1)$ \\
\hline Ca/P & 1.54 & 1.83 & 1.71 & 1.76 \\
\hline
\end{tabular}

Recent work has shown that apatite compounds with appropriate morphological characteristics have better performance in biomedical applications. To better understand the effect of mechanochemical processes on the morphology of the synthesized nanopowder, TEM analyses were conducted. Fig. 8a shows the TEM and HRTEM images of the sample $\mathrm{x}=0$ as-mechanosynthesized and Fig. $8 \mathbf{b}$ shows the TEM and HRTEM micrographs of sample $\mathrm{x}=1$ calcined at $500^{\circ} \mathrm{C}$. 

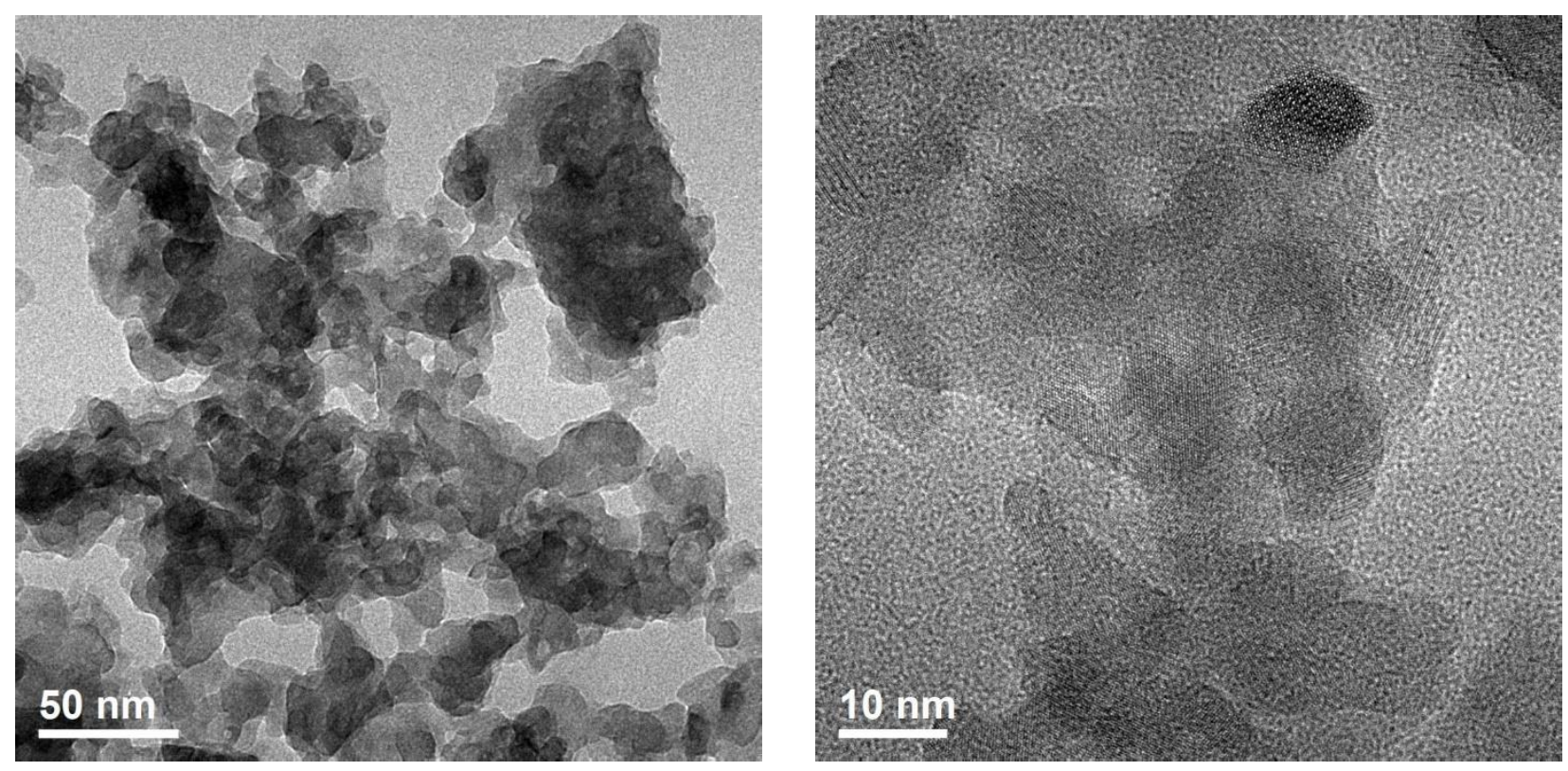

(a)
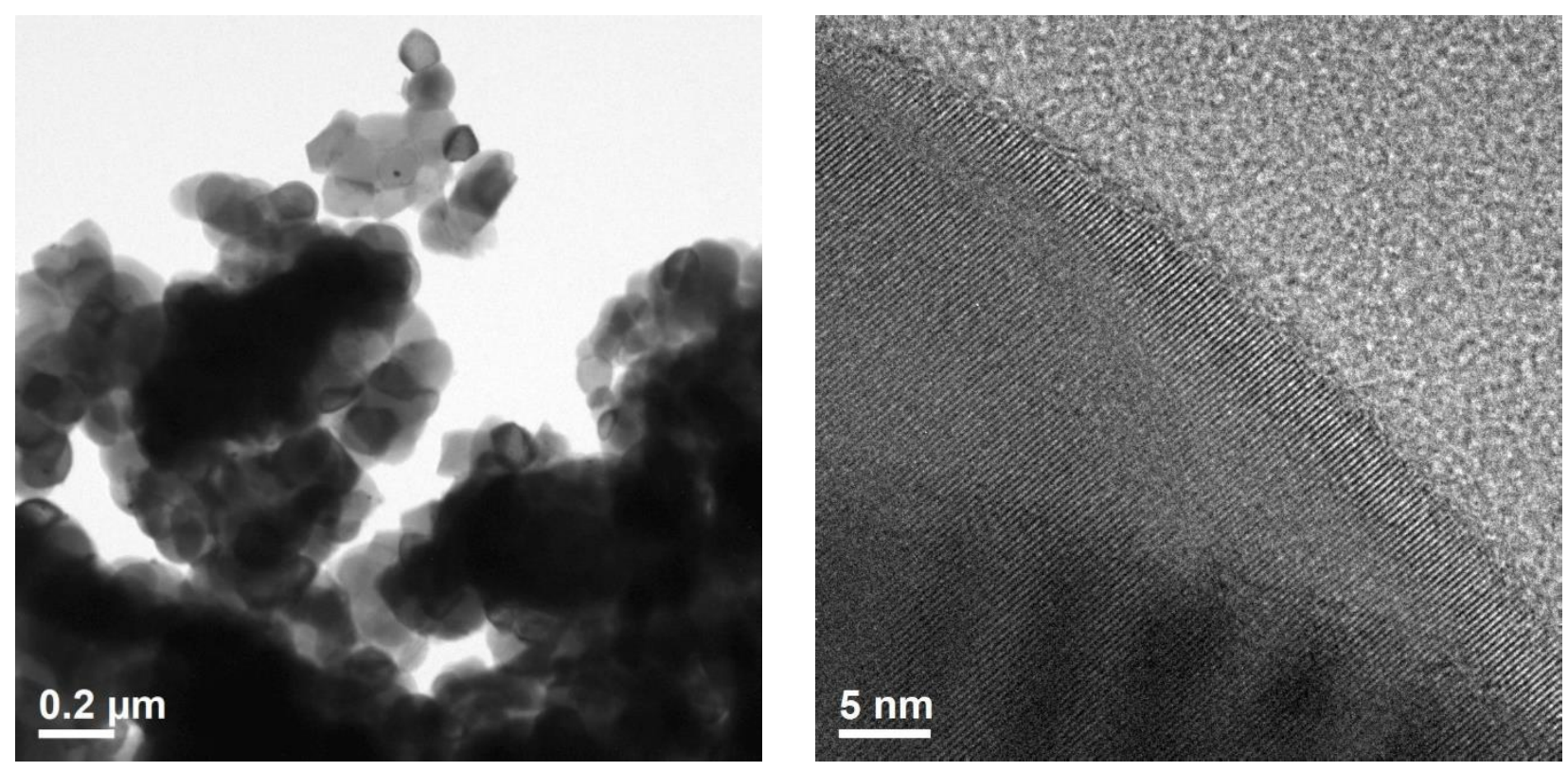

(b)

Fig. 8. TEM and HR-TEM images of unsubstituted HFA (a) $x=0$ untreated, (b) $x=1$, calcined at $500^{\circ} \mathrm{C}$ for 1 hour

All the microstructures consist of micrometer-scale aggregates made of nanocrystalline crystallites. Similar morphologies and sizes are observed for substituted and unsubstituted powders, both untreated and calcined. The TEM images indicate that the particles are nanometric in size and 
almost spherical. During the milling process, particles have a strong tendency to aggregate as demonstrated by DLS analysis (Table S2). Recent work has reported that when two adjacent primary particles collide, coalescence can occur if the two particles have the same crystallographic orientation. Since the secondary particles are very small, it is reasonable to assume that they continue to collide and coalesce, which lead to aggregation [24], [65]. High-resolution TEM (Fig. 8a and 8b) show that grains are in fact an assembly of nano-crystallites, in accordance with XRD results (Table $\mathbf{1}$ and Table 2). These images also show the very good crystallinity of the samples. Mean crystallite size observed by TEM, around $50 \mathrm{~nm}$ for the sample $\mathrm{x}=1$ treated, is in agreement with XRD results. Nevertheless, some particle diameters are higher (Fig. 8b), proving a relative large crystallite size distribution, which is typical of mechanosynthesized powder [18].

Fig. S1. shows the zeta potential versus $\mathrm{pH}$ curves for HFA samples for $\mathrm{x}=0$ and 0.5 (untreated and calcined). Since synthesized samples dissociate at $\mathrm{pH}<6$, the measurements took place at $\mathrm{pH} \geq 6$. Cosubstituted HFA particles have a surface charge that can vary depending on the $\mathrm{pH}$ or other adsorbed species in an aqueous medium. Indeed, the surface of hydroxyfluorapatite displays amphoteric properties due to specific adsorption of $\mathrm{H}^{+}$and $\mathrm{OH}^{-}$, leading to different species at surface, such as $\mathrm{Ca}-\mathrm{OH} / \mathrm{Ca}-\mathrm{OH}_{2}{ }^{+}$or $\mathrm{P}-\mathrm{O}-\mathrm{POH}$ [67]. The higher the zeta potential of the particles, the greater the tendency of the particles to repel each other, which promotes dispersion [67], [68]. All the curves clearly indicate that the zeta potential values are negative for $\mathrm{pH} \geq 6$ and become larger in absolute value when $\mathrm{pH}$ increases, this is in agreement with previous measurements on hydroxyapatite [68]. The differences in absolute value, between the samples at a given $\mathrm{pH}$, may come from adsorption or desorption of the different ions present in the structure and so at the surface: phosphate, calcium, lithium and carbonate ions [68].

The hydrodynamic diameters determined thanks to DLS measurements $\left(D_{H}\right)$ for the powders untreated and calcined at $500^{\circ} \mathrm{C}$ show that the synthesized powders are aggregated as indicated in Table S2. It is in agreement with TEM observations (Fig. 8). Indeed, the values are in the micrometric 
range while crystallites are in the nanometric range $\left(\mathrm{D}_{\mathrm{XRD}}\right.$, Table $\mathbf{1}$ and Fig. 8). It seems that an increase of $\mathrm{x}$ for the untreated samples leads to larger aggregates as shown in Table S2. But for calcined powders the value of $\mathrm{D}_{\mathrm{H}}$ seems to decrease with the increase of $\mathrm{x}$. The heat treatment seems to decompose some aggregates, leading to smaller polycrystalline grains size.

\subsection{Sintering of a composition of interest}

Based on the microstructural characterizations, the substituted samples with $x=0.5$ and $x=1$ have more than $90 \%$ of apatite. For this reason, we performed a dilatometric test on the sample with $\mathrm{x}=1$. Fig. 9 shows the temperature-dependent shrinkage evolution of untreated HFA powder $(x=1)$ during sintering in an SPS apparatus. The first shrinkage of the order of $0.5 \mathrm{~mm}$ at room temperature is the result of cold compaction under $75 \mathrm{MPa}$. The second shrinkage of $0.4 \mathrm{~mm}$ occurs when heating up to about $216^{\circ} \mathrm{C}$ and corresponds to the departure of water molecules adsorbed on the apatite surface. The third shrinkage of the order of $1 \mathrm{~mm}$ occurs in a single step from $580^{\circ} \mathrm{C}$ and continues until about $650{ }^{\circ} \mathrm{C}$. It corresponds to the sintering of the powder. Densification in HA is governed by the diffusion of hydroxide ions. The partial substitution of hydroxide ions by fluoride ions reduces the mobility of these latter in HFA. Of all the HFA, apatite with a OH:F ratio of 1:1 has the poorest sinterability [60]. Conversely, the substitution of phosphate groups by carbonate groups in HA promotes densification. Lithium seems to have the same effect on sintering. Its insertion in HA activates sintering [69]. Density measurements could have not been performed to confirm the high densification level. Indeed, the sample was broken in small pieces due to its very low thickness (only $0.3 \mathrm{~g}$ of powder). However, the dilatometric test showed that densification of such powder could be achieved below $650^{\circ} \mathrm{C}$. 


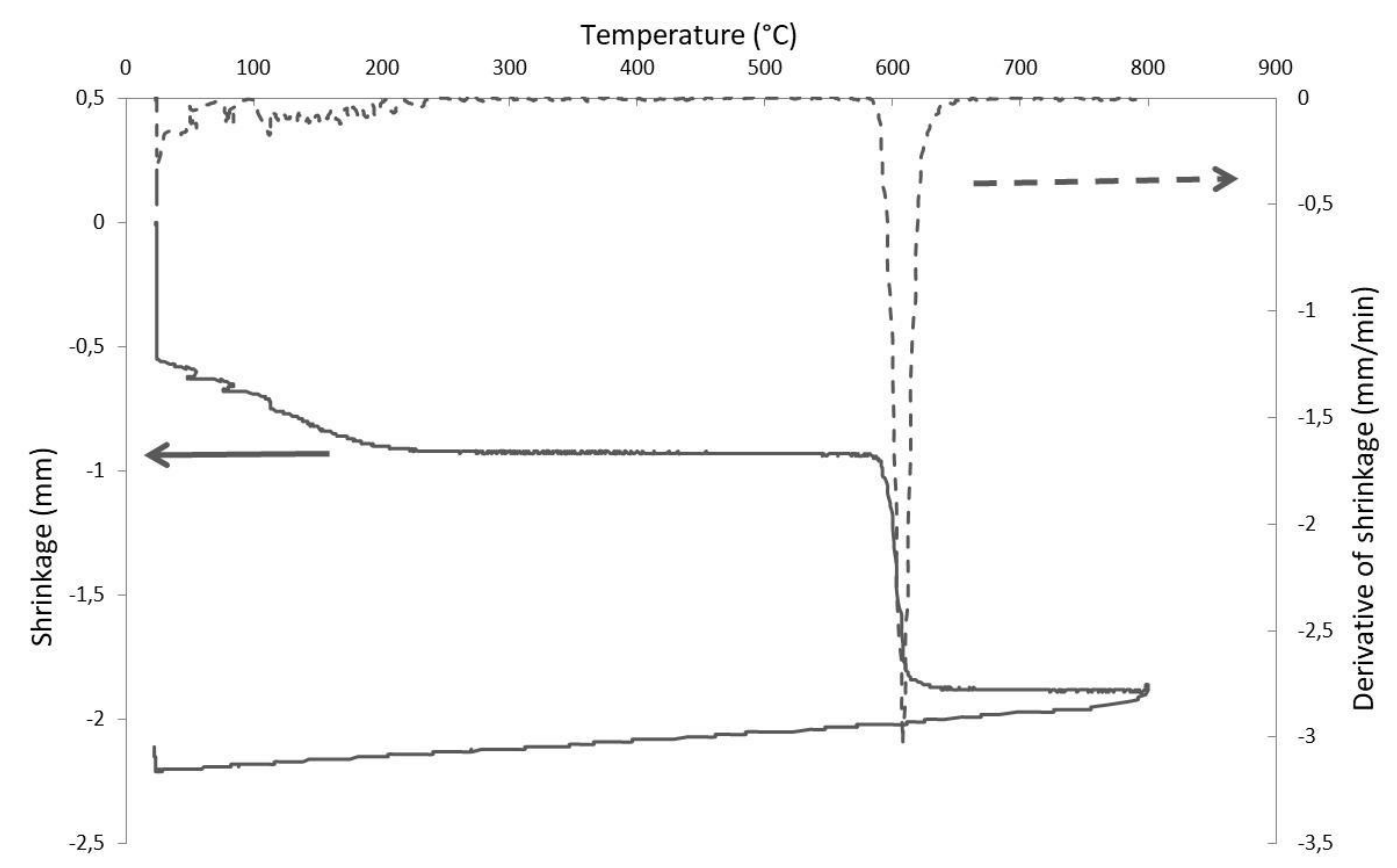

Fig. 9. Sintering curve as a function of temperature of as-mechanosynthesized $\mathrm{Ca}_{10-\mathrm{x}} \mathrm{Li}_{\mathbf{x}}\left(\mathrm{PO}_{4}\right)_{6-\mathrm{x}}\left(\mathrm{CO}_{3}\right)_{\mathrm{x}}(\mathrm{OH}) \mathrm{F}$ powder $(\mathrm{x}=1)$

Fig. 10 shows the XRD diffractograms of the $\mathrm{x}=1$ sample untreated, calcined at $500^{\circ} \mathrm{C}$ and sintered at $800^{\circ} \mathrm{C}$. After sintering, the sample contains apatite and calcite, as after calcination. However, the amount of calcite is higher in the sintered sample (Table 4), suggesting that the apatite decarbonation is more pronounced. This decarbonation process is corroborated by the evolution of the cell parameters. However, the application of an appropriate pressure during the SPS cycle can reduce decarbonation significantly [70].

After SPS sintering of the co-substituted hydroxyfluorapatite powder, the crystallite size remains the same than that of the untreated-powder sintered (about $15 \mathrm{~nm}$ ) (Fig. S2). No grain growth is noticed, contrary to after a calcination (Table 4), this can be explained by the pressure applied during this fast sintering. After the sintering of the powder, the lattice strains rate remain also the same. 


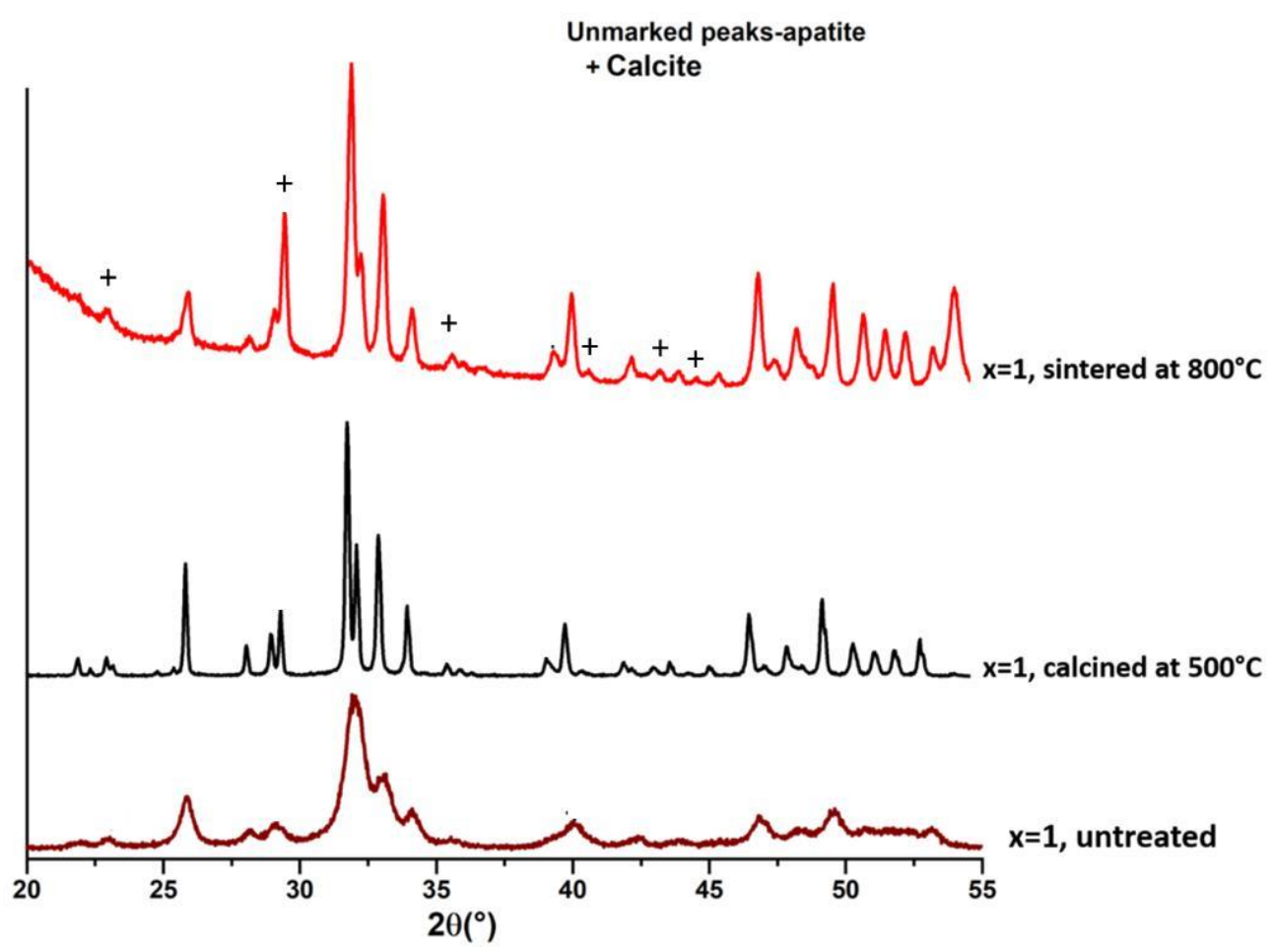

Fig. 10. XRD diffractograms of substituted HFA $(x=1)$, untreated, calcined at $500^{\circ} \mathrm{C}$ and sintered at $800^{\circ} \mathrm{C}$

Table 4. Percentages of phases present in substituted HFA powders $(x=1)$ untreated, calcined at $500^{\circ} \mathrm{C}$ and sintered at $800^{\circ} \mathrm{C}$, hexagonal cell parameters, lattice strain and crystallite size (D) of the apatite phase obtained with the Halder \& Wagner method and crystallinity rate.

\begin{tabular}{|c|c|c|c|}
\hline & $\mathbf{x}=\mathbf{1}$ untreated & $\mathbf{x}=\mathbf{1}$ calcined at $\mathbf{5 0 0}^{\circ} \mathbf{C}$ & $\mathbf{x}=\mathbf{1}$ sintered at $\mathbf{~ 0 0}^{\circ} \mathbf{C}$ \\
\hline Apatite (wt. \%) $\mathbf{0 . 1} \%$ & 89.9 & 95.4 & 84.1 \\
\hline Calcite (wt. \%) $\mathbf{0 . 1} \%$ & 7.5 & 4.6 & 15.9 \\
\hline \% Crystallinity & 30 & 79 & 33 \\
\hline $\mathbf{a}(\AA)$ & $9.353(5)$ & $9.391(3)$ & $9.403(7)$ \\
\hline $\mathbf{c}(\AA)$ & $6.907(1)$ & $6.889(2)$ & $6.892(4)$ \\
\hline
\end{tabular}




\begin{tabular}{|c|c|c|c|}
\hline $\mathbf{D}(\mathbf{2} \mathbf{~ n m})$ & 17 & 48 & 13 \\
\hline Lattice strain & 0.42 & 0.11 & 0.43 \\
\hline
\end{tabular}

\section{Conclusion}

In the present study, mechanosynthesis was used to synthesize lithium-substituted carbonate hydroxyfluorapatite nanopowders under optimal conditions. Structural and spectroscopic analyses confirm the incorporation of lithium and carbonate into the apatite structure for $x<2$. The results suggest that the structural features of the obtained samples were influenced notably by the degree of carbonate substitution in the HFA lattice. Substitution causes contraction in the $a$-axis and elongation of the $c$-axis as well as a decrease in the crystallinity of the powder. Spectroscopic analyses show that carbonated B-type apatite was obtained. The amount of apatite decreased drastically from 99.6 to $51.8 \%$ when the carbonate content increased from $\mathrm{x}=0$ to $\mathrm{x}=2$, whereas the percentage of unreacted calcite and lithium carbonate increases. It was shown that the removal of carbonate present in the apatite framework occurred at temperatures between 500 and $650{ }^{\circ} \mathrm{C}$. An heat treatment at $500^{\circ} \mathrm{C}$ allowed to decrease the secondary phases from 48 to $10 \%$, crystallite size and crystallinity were increased. The increased incorporation of lithium into carbonate apatite observed in this study induces a disorder in the carbonate HFA network and allows $\mathrm{Li}^{+}$ions to enter the apatite network without altering the crystal structure. According to the results obtained for $\mathrm{x}$ greater than 1 , the substitution causes a saturation of the solid solution. TEM observations show that untreated and calcined powders consist mainly of almost spherical aggregated nanoparticles. The SPS sintering at temperature below $650^{\circ} \mathrm{C}$ of the as-mechanosynthesized substituted sample with $\mathrm{x}=1$ allowed to maintain the nanometric size of the crystallites and preserve the apatite structure.

\section{Acknowledgments}


We would like to thanks the help of N. Geoffroy for XRD analyses, Dr. F. Herbst for EDX investigations, Dr. R. Chassagnon for TEM analyses, and Dr. J. Boudon for TGA analyses.

\section{Funding Sources}

The authors acknowledge support from the Graduate School EUR-EIPHI (17-EURE-0002), the Région Bourgogne Franche-Comté and the European Union through the PO FEDER-FSE Bourgogne 2014/2020.

\section{References}

[1] N. Strutynska, O. Livitska, S. Prylutska, Y. Yumyna, P. Zelena, L. Skivka, A. Malyshenko, L. Vovchenko, V. Strelchuk, Y. Prylutskyy, N. Slobodyanik, U. Ritter, « New nanostructured apatite-type $\left(\mathrm{Na}^{+}, \mathrm{Zn}^{2+}, \mathrm{CO}_{3}{ }^{2-}\right)$-doped calcium phosphates: Preparation, mechanical properties and antibacterial activity », Journal of Molecular Structure, vol. 1222, p. 128932, 2020, doi: 10.1016/j.molstruc.2020.128932.

[2] S. Raynaud, E. Champion, D. Bernache-Assollant, P. Thomas, « Calcium phosphate apatites with variable $\mathrm{Ca} / \mathrm{P}$ atomic ratio $\mathrm{I}$. Synthesis, characterisation and thermal stability of powders », Biomaterials, vol. 23, Art. no 4, 2002, doi: 10.1016/S0142-9612(01)00218-6.

[3] M. J. Gorbunoff, « The interaction of proteins with hydroxyapatite. I. Role of protein charge and structure », Anal. Biochem., vol. 136, Art. n 2, 1984, doi: 10.1016/0003-2697(84)90239-2.

[4] C. Rey, J. L. Miquel, L. Facchini, A. P. Legrand, M. J. Glimcher, « Hydroxyl groups in bone mineral », Bone, vol. 16, Art. n 5, 1995, doi: 10.1016/8756-3282(95)00101-I.

[5] M. J. Gorbunoff, S. N. Timasheff, « The interaction of proteins with hydroxyapatite. III. Mechanism », Anal. Biochem., vol. 136, nº 2, Art. n 2, 1984, doi: 10.1016/0003-2697(84)90241-0.

[6] Y. Lu, Ch. Zhang, Sh. Yuan, C. Zhang, J. Wang, H. Kong, G. Jia, « Novel $\mathrm{CsPbBr}_{1.5} \mathrm{I}_{1.5} @ \mathrm{SrHAp}$ single-phase white-light emitting phosphors: Facile synthesis, formation process, enhanced stability, and color-tunable luminescence », Chemical Engineering Journal, vol. 426, p. 130809, 2021, doi: 10.1016/j.cej.2021.130809. 
[7] P. J. Panteix, I. Julien, D. Bernache-Assollant, P. Abélard, « Synthesis and characterization of oxide ions conductors with the apatite structure for intermediate temperature SOFC », Materials Chemistry and Physics, vol. 95, Art. n 2-3, 2006, doi: 10.1016/j.matchemphys.2005.06.040.

[8] S. Le Gallet, L. Campayo, E. Courtois, S. Hoffmann, Yu. Sourire, F. Bernard, F. Bart, « Spark plasma sintering of iodine-bearing apatite », Journal of Nuclear Materials, vol. 400, Art. ${ }^{\circ}$ 3, 2010, doi: 10.1016/j.jnucmat.2010.03.011.

[9] A. Mechay, H. Elfeki, F. Schoenstein, F. Tétard, N. Jouini, «Effect of spark plasma sintering process on the microstructure and mechanical properties of Nano crystalline hydroxyapatite ceramics prepared by hydrolysis in polyol medium », International Journal of Advanced Chemistry, vol. 2, Art. $\mathrm{n}^{\mathrm{o}} 2$, 2014, doi: 10.14419/ijac.v2i2.2393.

[10] M. Valletregi, « Synthesis and characterisation of calcium deficient apatite », Solid State Ionics, vol. 101-103, p. 1279-1285, 1997, doi: 10.1016/S0167-2738(97)00213-0.

[11] M. Azami, S. Jalilifiroozinezhad, M. Mozafari, M. Rabiee, « Synthesis and solubility of calcium fluoride/hydroxy-fluorapatite nanocrystals for dental applications », Ceramics International, vol. 37, Art. $\mathrm{n}^{\mathrm{o}}$ 6, 2011, doi: 10.1016/j.ceramint.2011.02.025.

[12] L. M. Rodríguez-Lorenzo, J. N. Hart, K. A. Gross, «Influence of fluorine in the synthesis of apatites. Synthesis of solid solutions of hydroxy-fluorapatite », Biomaterials, vol. 24, Art. no 21, 2003, doi: 10.1016/S0142-9612(03)00259-X.

[13] R. H. Ali, H. Ageorges, S. Nasr, E. B. Salem, « Zinc and strontium co-substituted hydroxyfluorapatite: Synthesis, sintering and mechanical properties », Materials Research Bulletin, vol. 112, p. 84-94, 2019, doi: 10.1016/j.materresbull.2018.11.042.

[14] H. Ammar, S. Nasr, H. Ageorges, E. B. Salem, « Sintering and mechanical properties of magnesium containing hydroxyfluorapatite », J Aust Ceram Soc, 56, p. 931-942, 2019, doi: $10.1007 / \mathrm{s} 41779-019-00422-7$.

[15] H. Badran, I. S. Yahia, M. S. Hamdy, N. S. Awwad, «Lithium-doped hydroxyapatite nanocomposites: Synthesis, characterization, gamma attenuation coefficient and dielectric properties », Radiation Physics and Chemistry, vol. 130, p. 85-91, 2017, doi:

10.1016/j.radphyschem.2016.08.001. 
[16] H. Hajji, S. Nasr, N. Millot, E. B. Salem, « Study of the effect of milling parameters on mechanosynthesis of hydroxyfluorapatite using the Taguchi method », Powder Technology, vol. 356, p. 566-580, 2019, doi: 10.1016/j.powtec.2019.08.087.

[17] M. Abdellaoui, C. Djega-Mariadassou, E. Gaffet, « Structural study of Fe-Si nanostructured materials », Journal of Alloys and Compounds, vol. 259, Art. n 1-2, 1997, doi: 10.1016/S09258388(97)00102-3.

[18] N. Millot, S. Begin-Colin, P. Perriat, G. Le Caër, « Structure, Cation Distribution, and Properties of Nanocrystalline Titanomagnetites Obtained by Mechanosynthesis: Comparison with Soft Chemistry », Journal of Solid State Chemistry, vol. 139, Art. n 1, 1998, doi: 10.1006/jssc. 1998.7808 .

[19] M. Vlasova, A. Fedotov, I. Mendoza Torrez, M. Kakazey, V. Komlev, P. A. Marquez Aguilar, «Mechanosynthesis of hydroxyapatite-ferrite composite nanopowder », Ceramics International, vol. 43, Art. $\mathrm{n}^{\mathrm{o}}$ 8, 2017, doi: 10.1016/j.ceramint.2017.02.020.

[20] I. Nikčević, V. Jokanović, M. Mitrić, Z. Nedić, D. Makovec, D. Uskoković, «Mechanochemical synthesis of nanostructured fluorapatite/fluorhydroxyapatite and carbonated fluorapatite/fluorhydroxyapatite », Journal of Solid State Chemistry, vol. 177, Art. n 7, 2004, doi: 10.1016/j.jssc.2004.03.024.

[21] C. C. Silva, A. G. Pinheiro, M. A. R. Miranda, J. C. Góes, A. S. B. Sombra, « Structural properties of hydroxyapatite obtained by mechanosynthesis », Solid State Sciences, vol. 5, Art. n 4, 2003, doi: 10.1016/S1293-2558(03)00035-9.

[22] A.J. Coreño, A.O. Coreño, R. J. J. Cruz, C.C. Rodríguez, « Mechanochemical synthesis of nanocrystalline carbonate-substituted hydroxyapatite », Optical Materials, vol. 27, Art. nº 7, 2005, doi: 10.1016/j.optmat.2004.11.025.

[23] S. Pokhrel, «Hydroxyapatite: Preparation, Properties and Its Biomedical Applications », Advances in Chemical Engineering and Science, vol. 08, Art. $\mathrm{n}^{\mathrm{o}} 4,2018$, doi: 10.4236/aces.2018.84016.

[24] H. Ashrafizadeh, M. Ashrafizaadeh, «Influence of processing parameters on grinding mechanism in planetary mill by employing discrete element method », Advanced Powder Technology, vol. 23, Art. nº 6, 2012, doi: 10.1016/j.apt.2011.09.002. 
[25] O. Kaygili, S. Keser, T. Ates, F. Yakuphanoglu, « Synthesis and characterization of lithium calcium phosphate ceramics », Ceramics International, vol. 39, Art. nº 7, 2013, doi: 10.1016/j.ceramint.2013.03.037.

[26] N. Matsumoto, K. Yoshida, K. Hashimoto, Y. Toda, « Thermal stability of $\beta$-tricalcium phosphate doped with monovalent metal ions », Materials Research Bulletin, vol. 44, Art. $\mathrm{n}^{\circ}$ 9, 2009, doi: 10.1016/j.materresbull.2009.05.012.

[27] A. P. M. Shainberg, P. Val’erio, A. Zonari, F. N. Oktar, L. S. Ozyegin, M. P. F. Grac sa, M.F. Leite, A. M. Goes, « Attachment and Proliferation of Osteoblasts on Lithium-Hydroxyapatite Composites », Advances in Materials Science and Engineering, vol. 2012, p. 1-10, 2012, doi: $10.1155 / 2012 / 650574$.

[28] I. Mayer, U. Berger, A. Markitziu, I. Gidalia, « The uptake of lithium ions by synthetic carbonated hydroxyapatite », Calcif Tissue Int, vol. 38, n 5, p. 293-295, 1986, doi: 10.1007/BF02556609.

[29] R.C. Popescu, P.E. Florian, G.E. Stan, G. Popescu-Pelin, I. Zgura, M. Enculescu, F.N. Oktar, R. Trusca, L.E. Sima, A. Roseanu, L. Duta, «Physical-chemical characterization and biological assessment of simple and lithium-doped biological-derived hydroxyapatite thin films for a new generation of metallic implants », Applied Surface Science, vol. 439, p. 724-735, 2018, doi: 10.1016/j.apsusc.2018.01.008.

[30] Th. Leventouri, B. C. Chakoumakos, H. Y. Moghaddam, V. Perdikatsis, « Powder neutron diffraction studies of a carbonate fluorapatite », J. Mater. Res., vol. 15, Art. n 2, 2000, doi: 10.1557/JMR.2000.0076.

[31] R. Astala, M. J. Stott, « First Principles Investigation of Mineral Component of Bone: $\mathrm{CO}_{3}$ Substitutions in Hydroxyapatite », Chem. Mater., vol. 17, Art. n ${ }^{\circ} 16,2005$, doi: 10.1021/cm050523b. [32] J. C. Elliott, Structure and Chemistry of the Apatites and Other Calcium Orthophosphates. Amsterdam: Elsevier Science, 1st Edition - April 28, 1994, eBook ISBN: 9781483290317

[33] T. I. Ivanova, O. V. Frank-Kamenetskaya, A. B. Kol’tsov, V. L. Ugolkov, « Crystal Structure of Calcium-Deficient Carbonated Hydroxyapatite. Thermal Decomposition », Journal of Solid State Chemistry, vol. 160, Art. no 2, 2001, doi: 10.1006/jssc.2000.9238. 
[34] R. M. Wilson, S. E. P. Dowker, J. C. Elliott, « Rietveld refinements and spectroscopic structural studies of a Na-free carbonate apatite made by hydrolysis of monetite », Biomaterials, vol. 27, Art. $\mathrm{n}^{\mathrm{o}} 27,2006$, doi: 10.1016/j.biomaterials.2006.04.033.

[35] M. E. Fleet, X. Liu, « Location of type B carbonate ion in type A-B carbonate apatite synthesized at high pressure », Journal of Solid State Chemistry, vol. 177, Art. nº 9, 2004, doi: 10.1016/j.jssc.2004.04.002.

[36] M. E. Fleet, «Infrared spectra of carbonate apatites: v2-Region bands », Biomaterials, vol. 30, no 8, p. 1473-1481, 2009, doi: 10.1016/j.biomaterials.2008.12.007.

[37] M. E. Fleet, X. Liu, « Local structure of channel ions in carbonate apatite », Biomaterials, vol. 26, Art. $\mathrm{n}^{\mathrm{o}}$ 36, 2005, doi: 10.1016/j.biomaterials.2005.05.025.

[38] C. Drouet, F. Bosc, M. Banu, C. Largeot, C. Combes, G. Dechambre, C. Estournès, G. Raimbeaux, C. Rey, « Nanocrystalline apatites: From powders to biomaterials », Powder Technology, vol. 190, Art. n 1-2, 2009, doi: 10.1016/j.powtec.2008.04.041.

[39] H. Hajji, M. Abdellaoui, L. Maurizi, S. Nasr, N. Millot, E. Ben Salem, « Kinematic modelisation and parametric study of mechanosynthesis of hydroxyfluorapatite », Advanced Powder Technology, Vol. 32, issue 10, p. 3585-3600, 2021, doi: 10.1016/j.apt.2021.08.013.

[40] N. C. Halder, C. N. J. Wagner, « Separation of particle size and lattice strain in integral breadth measurements », Acta Cryst, vol. 20, n 2, p. 312-313, 1966, doi: 10.1107/S0365110X66000628.

[41] A. Mahmoud, M. Echabaane, K. Omri, J. Boudon, L. Saviot, N. Millot R. Ben Chaabane, « Cu-Doped ZnO Nanoparticles for Non-Enzymatic Glucose Sensing », Molecules, vol. 26, $\mathrm{n}^{\circ}$ 4, $\mathrm{p}$. 929, 2021, doi: 10.3390/molecules26040929.

[42] M. Kavitha, R. Subramanian, K. S. Vinoth, R. Narayanan, G. Venkatesh, N. Esakkiraja, «Optimization of process parameters for solution combustion synthesis of Strontium substituted Hydroxyapatite nanocrystals using Design of Experiments approach », Powder Technology, vol. 271, p. 167-181, 2015, doi: 10.1016/j.powtec.2014.10.046.

[43] R. D. Shannon, « Revised effective ionic radii and systematic studies of interatomic distances in halides and chalcogenides », Acta Cryst A, vol. 32, Art. n 5, 1976, doi:

10.1107/S0567739476001551. 
[44] E. Ben Salem, S. Nasr, E. Gaudin, K. Bouzouita, « Synthesis of magnesium and carbonate co-substituted fluoroapatites by hydrothermal method », Ann. Chim. Sci. Mat., vol. 36, Art. no 4-5-6, 2011, doi: 10.3166/acsm.36.205-216.

[45] M. Wang, R. Qian, M. Bao, C. Gu, P. Zhu, « Raman, FT-IR and XRD study of bovine bone mineral and carbonated apatites with different carbonate levels », Materials Letters, vol. 210, p. 203-206, 2018, doi: 10.1016/j.matlet.2017.09.023.

[46] M. Hidouri, S. V. Dorozhkin, « Structure and thermal stability of sodium and carbonate-cosubstituted strontium hydroxyfluorapatites », New J. Chem., vol. 42, Art. n 11, 2018, doi: 10.1039/C8NJ00950C.

[47] A. C. Deymier, A. K. Nair, B. Depalle, Z. Qin, K. Arcot, C. Drouet, C. H. Yoder, M. J. Buehler, S. Thomopoulos, Guy M. Genin, J. D. Pasteris, « Protein-free formation of bone-like apatite: New insights into the key role of carbonation », Biomaterials, vol. 127, p. 75-88, 2017, doi: 10.1016/j.biomaterials.2017.02.029.

[48] M. H. Brooker, J. Wang, « Raman and infrared studies of lithium and cesium carbonates », Spectrochimica Acta Part A: Molecular Spectroscopy, vol. 48, Art. nº 7, 1992, doi: 10.1016/05848539(92)80176-W.

[49] A. Antonakos, E. Liarokapis, T. Leventouri, « Micro-Raman and FTIR studies of synthetic and natural apatites », Biomaterials, vol. 28, Art. n ${ }^{\circ} 19,2007$, doi:

10.1016/j.biomaterials.2007.02.028.

[50] I. Rehman, W. Bonfield, « Characterization of hydroxyapatite and carbonated apatite by photo acoustic FTIR spectroscopy », Journal of Materials Science: Materials in Medicine, vol. 8, Art. ${ }^{\mathrm{o}}$ 1, 1997, doi: 10.1023/A:1018570213546.

[51] G. Penel, G. Leroy, C. Rey, B. Sombret, J. P. Huvenne, E. Bres, «Infrared and Raman microspectrometry study of fluor-fluor-hydroxy and hydroxy-apatite powders », Journal of Materials Science Materials in Medicine, vol. 8, Art. $\mathrm{n}^{0}$ 5, 1997, doi: 10.1023/A:1018504126866.

[52] G. Penel, G. Leroy, C. Rey, E. Bres, « MicroRaman Spectral Study of the $\mathrm{PO}_{4}$ and $\mathrm{CO}_{3}$ Vibrational Modes in Synthetic and Biological Apatites », Calcified Tissue International, vol. 63, Art. $n^{\circ} 6,1998$, doi: 10.1007/s002239900561. 
[53] J. Sun, Z. Wu, H. Cheng, Z. Zhang, R. L. Frost, « A Raman spectroscopic comparison of calcite and dolomite », Spectrochimica Acta Part A: Molecular and Biomolecular Spectroscopy, vol. 117, p. 158-162, 2014, doi: 10.1016/j.saa.2013.08.014.

[54] K. Tônsuaadu, M. Peld, T. Leskelä, R. Mannonen, L. Niinistö, M. Veiderma, « A thermoanalytical study of synthetic carbonate-containing apatites », Thermochimica Acta, vol. 256, Art. $\mathrm{n}^{\mathrm{o}}$ 1, 1995, doi: 10.1016/0040-6031(94)02169-O.

D. Aymes, «Experimental set up for determining the temperature-oxygen partial pressure conditions during synthesis of spinel oxide nanoparticles », Solid State Ionics, vol. 101-103, p. 261-264, 1997, doi: 10.1016/S0167-2738(97)84040-4.

[56] T. Belin, N. Millot, F. Villiéras, O. Bertrand, J. P. Bellat, « Structural Variations as a Function of Surface Adsorption in Nanostructured Particles », J. Phys. Chem. B, vol. 108, Art. n ${ }^{0} 17$, 2004, doi: 10.1021/jp0310899.

[57] H. Bieber, P. Gilliot, M. Gallart, N. Keller, V. Keller, S. Bégin-Colin, C. Pighini, N. Millot, «Temperature dependent photoluminescence of photocatalytically active titania nanopowders », Catalysis Today, vol. 122, Art. nº 1-2, 2007, doi: 10.1016/j.cattod.2007.01.036.

[58] R. Ševčík, P. Mácová, « Localized quantification of anhydrous calcium carbonate polymorphs using micro-Raman spectroscopy », Vibrational Spectroscopy, vol. 95, p. 1-6, 2018, doi: 10.1016/j.vibspec.2017.12.005.

[59] J. Ito, Y. Matsushima, H. Unuma, N. Horiuchi, K. Yamashita, M. Tajika, « Preparation and properties of pressureless-sintered dense calcite ceramics », Materials Chemistry and Physics, vol. 192, p. 304-310, 2017, doi: 10.1016/j.matchemphys.2017.01.062.

[60] N. Senamaud, «Calcination and sintering of hydroxyfluorapatite powders », Solid State Ionics, vol. 101-103, p. 1357-1362, 1997, doi: 10.1016/S0167-2738(97)00242-7.

[61] Z. Zyman, M. Tkachenko, « $\mathrm{CO}_{2}$ gas-activated sintering of carbonated hydroxyapatites », Journal of the European Ceramic Society, vol. 31, Art. $\mathrm{n}^{\circ} 3$, 2011, doi:

10.1016/j.jeurceramsoc.2010.09.005.

[62] H. Juang, «Effect of calcination on sintering of hydroxyapatite », Biomaterials, vol. 17, Art. $\mathrm{n}^{\mathrm{o}} 21,1996$, doi: 10.1016/0142-9612(96)88882-X. 
[63] Y. X. Pang, X. Bao, «Influence of temperature, ripening time and calcination on the morphology and crystallinity of hydroxyapatite nanoparticles », Journal of the European Ceramic Society, vol. 23, Art. n 10, 2003, doi: 10.1016/S0955-2219(02)00413-2.

[64] R. Z. LeGeros, O. R. Trautz, E. Klein, J. P. LeGeros, « Two types of carbonate substitution in the apatite structure », Experientia, vol. 25, Art. nº 1, 1969, doi: 10.1007/BF01903856.

[65] A. Fahami, B. Nasiri-Tabrizi, G. W. Beall, B. Pingguan-Murphy, « Effect of ion concentration on mechanosynthesis of carbonated chlorapatite nanopowders », Materials Letters, vol. 146, p. 16-19, 2015, doi: 10.1016/j.matlet.2015.01.149.

[66] C. Mochales, R. M. Wilson, S. E. P. Dowker, M.-P. Ginebra, « Dry mechanosynthesis of nanocrystalline calcium deficient hydroxyapatite: Structural characterisation », Journal of Alloys and Compounds, vol. 509, Art. n 27, 2011, doi: 10.1016/j.jallcom.2011.04.033.

[67] L. Wu, W. Forsling, P. W. Schindler, « Surface complexation of calcium minerals in aqueous solution », Journal of Colloid and Interface Science, vol. 147, Art. nº 1, 1991, doi: 10.1016/00219797(91)90145-X.

[68] W. Janusz, E. Skwarek, « The study of the properties of the hydroxyapatite/electrolyte interface », Annales UMCS, Chemistry, vol. 64, Art. n 1, 2009, doi: 10.2478/v10063-008-0003-x.

[69] M. Safarzadeh, S. Ramesh, C.Y. Bronzage, H. Chandran, Y.C. Ching, A. Fauzi, M. Noor, S. Krishnasamy, W.D. Teng, « Sintering behaviour of carbonated hydroxyapatite prepared at different carbonate and phosphate ratios », Boletín de la Sociedad Española de Cerámica y Vidrio, vol. 59, Art. ${ }^{\mathrm{o}} 2$ 2, 2020, doi: 10.1016/j.bsecv.2019.08.001.

[70] N. Massoni, S. Le Gallet, S. Hoffmann, P. Launeau, Y. Grin, F. Bernard, « Sintering of synthetic barytocalcite $\mathrm{BaCa}\left(\mathrm{CO}_{3}\right)_{2}$, kutnahorite $\mathrm{CaMn}\left(\mathrm{CO}_{3}\right)_{2}$ and rhodochrosite $\mathrm{MnCO}_{3}$ for carbon14 sequestration », Journal of the European Ceramic Society, vol. 35, nº 1, p. 297-308, 2015, doi: 10.1016/j.jeurceramsoc.2014.08.002. 